\title{
DETECÇÃO E IDENTIFICAÇÃO DE Metarhizium anisopliae EM LARVAS DE Diatraea saccharalis POR PRIMERS ESPECÍFICOS
}

\section{RICARDO HENRI RODRIGUES DESTÉFANO}

\author{
Tese apresentada à Escola Superior de Agricultura \\ "Luiz de Queiroz", Universidade de São Paulo, \\ para obtenção do título de Doutor em Agronomia, \\ Área de Concentração: Microbiologia Agrícola.
}

\author{
PIRACICABA \\ Estado de São Paulo - Brasil
}

Abril - 2003 


\title{
DETECÇÃO E IDENTIFICAÇÃO DE Metarhizium anisopliae EM LARVAS DE Diatraea saccharalis POR PRIMERS ESPECÍFICOS
}

\section{RICARDO HENRI RODRIGUES DESTÉFANO}

Engenheiro Agrônomo

Orientador: Prof. Dr. CLAUDIO LUIZ MESSIAS

Tese apresentada à Escola Superior de Agricultura

"Luiz de Queiroz", Universidade de São Paulo, para obtenção do título de Doutor em Agronomia, Área de Concentração: Microbiologia Agrícola.

\author{
PIRACICABA \\ Estado de São Paulo - Brasil
}

Abril - 2003 


\section{Dados Internacionais de Catalogação na Publicação (CIP)} DIVISÃO DE BIBLIOTECA E DOCUMENTAÇÃO - ESALQ/USP

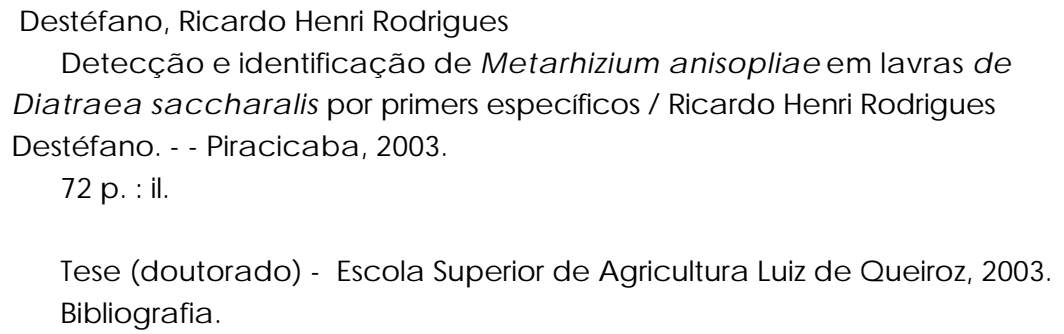

1. Broca (Inseto nocivo) 2. Controle biológico 3. Fungo entomopatogênico I. Título

CDD 632.78 


\section{AGRADECIMENTOS}

Ao Prof. Dr. Claudio Luiz Messias pelo estímulo e pela oportunidade propiciados para a realização deste trabalho.

Agradeço especialmente à Pesquisadora Dra. Suzete A. Lanza Destéfano, pela grande contribuição e inestimável ajuda, me estimulando a todo instante e sem dúvida valorizando em muito este trabalho com seus conhecimentos na área de Genética Molecular.

Agradeço ao Laboratório de Bacteriologia Vegetal do Instituto Biológico, Campinas, SP pela disponibilização do laboratório e equipamentos, onde parte do trabalho foi realizada.

Ao Pesquisador Dr. Júlio Rodrigues Neto pela amizade e colaboração na revisão deste trabalho.

À Dra. Valéria Maia Oliveira da Divisão de Recursos Microbianos do CPQBA/UNICAMP pela amizade e carinho dispensados, pelo profissionalismo e auxílio indispensável nas análises filogenéticas.

Ao Dr. Enrico De Beni Arrigoni do Centro de Tecnologia Copersucar Piracicaba, SP, pela cessão dos insetos utilizados neste estudo e pelas conversas profissionais construtivas.

Ao Prof. Dr. Gonçalo A. G. Pereira por permitir a realização dos experimentos de sequenciamento no Laboratório de Genômica e Expressão do Depto. Genética e Evolução/IB/UNICAMP.

Às Biólogas Denise Balani e Mariana Ferreira, pela gentileza, auxílio e empenho na realização de algumas práticas laboratoriais. 
Às Biólogas Cintia Losano Costa e Carla Judice Maria do Laboratório de Genômica e Expressão do DGE/IB/UNICAMP pelo empenho e profissionalismo demonstrados no auxílio nos experimentos de sequenciamento, e análises das seqüênciasde para o desenho dos primers específicos.

Às colegas de trabalho, Célia, Ernestina, Ana Rita e Patricia pela convivência amiga e saudável que elas propiciam, tornando nosso ambiente de trabalho bastante agradável.

À Universidade Estadual de Campinas, UNICAMP, ao Instituto de Biologia e ao Departamento de Genética e Evolução pela oportunidade de aperfeiçoamento acadêmico-profissional.

Aos meus queridos e amados filhos Ricardo Henri Rodrigues Lanza Destéfano e Guilherme Rodrigues Lanza Destéfano pela paciência e compreensão nos finais de semana confinados, dispensados ao meu trabalho. 


\section{SUMÁRIO}

Página

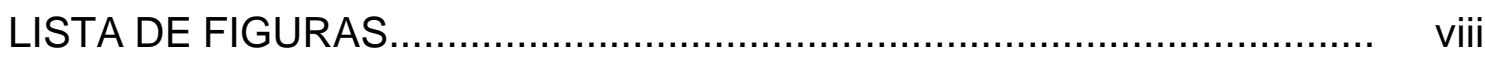

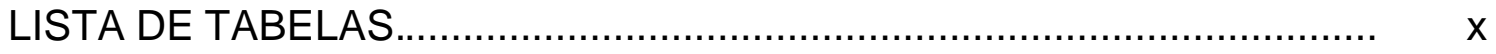

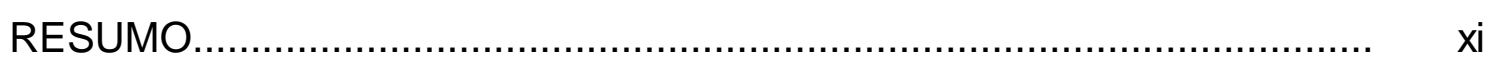

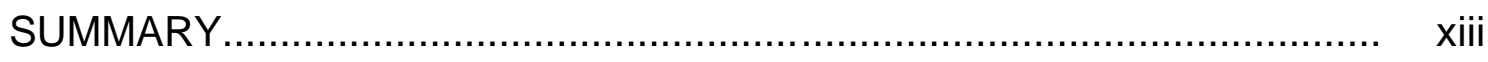

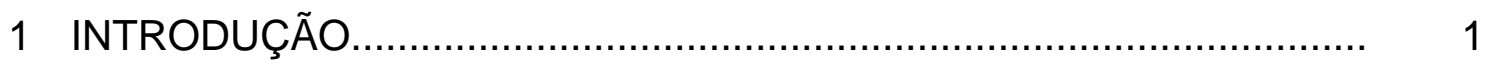

2 REVISÃO DE LITERATURA............................................... 4

2.1 O fungo Metarhizium anisopliae (Metsch.) Sorokin........................... 4

2.2 Patogenicidade e virulência................................................... 6

2.3 Marcadores moleculares................................................... 9

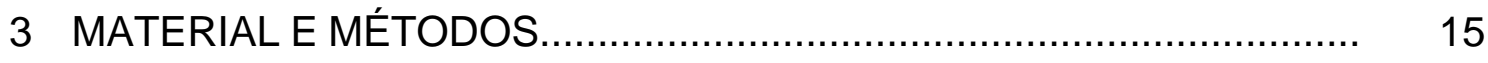

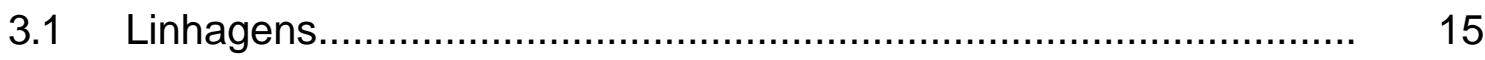

3.2 Meios de cultivo.......................................................... 15

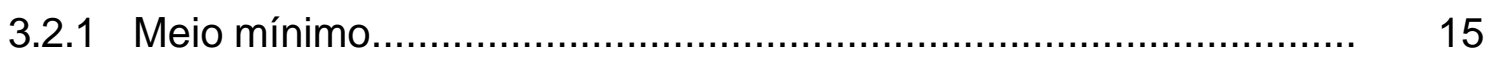

3.2 .2 Meio completo............................................................. 17

3.2.3 Solução de vitaminas................................................... 17

3.2.4 Meio de arroz.............................................................. 17

3.3 Soluções e tampões....................................................... 18

3.4 Obtenção de conídios para inoculação em meio líquido................... 19

3.5 Obtenção do micélio para extração de DNA ................................ 19

3.6 Hospedeiro.................................................................. 19

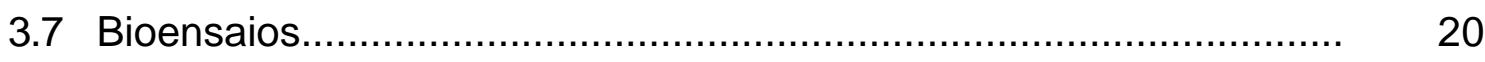


3.8 Preparação dos insetos após os bioensaios para extração de DNA........................................................................... 20

3.9 Extração de DNA em pequena escala.............................................. 21

3.10 Amplificação do DNA por PCR ..................................................... 22

3.11 Digestão dos produtos de PCR com endonucleases de restrição...................................................................... 23

3.12 Análise dos padrões de fingerprinting......................................... 24

3.13 Purificação dos produtos de amplificação

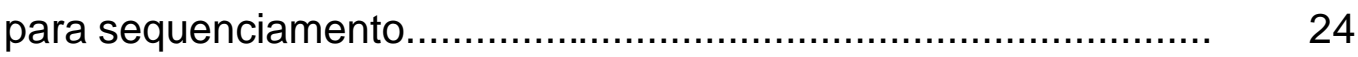

3.14 Sequenciamento da região ITS1 - 5.8S - ITS2 DNAr..................... 25

3.15 Análise filogenética............................................................. 25

3.16 Desenho e síntese dos oligonucleotídeos (primers)

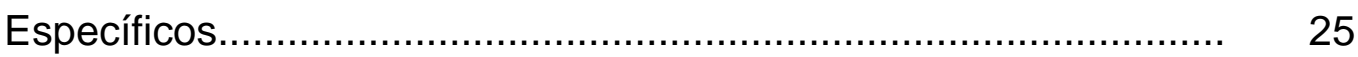

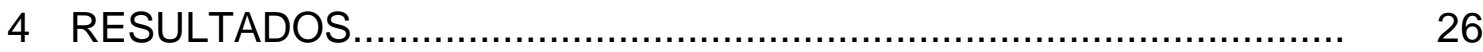

4.1 Amplificação do gene 18S DNAr e da região

ITS1 - 5.8S - ITS2 DNAr.......................................................... 26

4.1.1 Análise do gene 18S DNAr...................................................... 26

4.1.2 Análise da região ITS1 - 5.8S - ITS2 ......................................... 28

4.1.3 Análise de PCR-RFLP da região ITS1 - 5.8S - ITS2 ..................... 31

4.2 Sequenciamento da região ITS1 - 5.8S - ITS2 DNAr de diferentes espécies de Metarhizium e Beauveria bassiana............... 32

4.3 Análise filogenética da região ITS1 - 5.8S - ITS2 do operon ribossômico.................................................................... 33

4.4 Desenho de primers específicos................................................... 36

4.5 Detecção de M. anisopliae var. anisopliae em insetos Infectados.

4.6 RFLP dos fragmentos específicos obtidos para confirmação da detecção de M.a. var. anisopliae nos insetos infectados..................................................................... 40

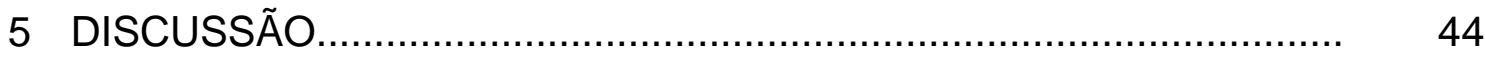




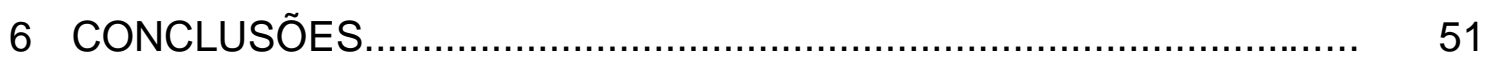

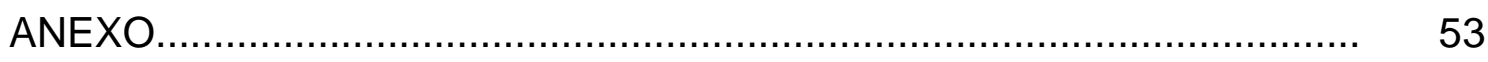

REFERÊNCIAS BIBLIOGRÁFICAS............................................... 58 


\section{LISTA DE FIGURAS}

Página

1 Esquema do par de primers NS1 e NS8 da sub-unidade menor $18 \mathrm{~S}$

2 Digestão do gene 18S com Afa I, Alu I, Dde I e Hae III

3 Esquema dos primers utilizados para amplificação da região intergênica.

4 Digestão da região espaçadora ITS com Afa I, Alu I, Dde I e Hae III

5 Digestão da região espaçadora ITS com Hpa ll e Sau 3A I

6 Dendrograma de similaridade obtido com o coeficiente de Dice.

7 Amplificação da região ITS em diferentes espécies de Metarhizium e Beauveria.

8 Dendrograma resultante do alinhamento das seqüências ITS1 - 5.8S - ITS2 DNAr de diferentes espécies de $M$. anisopliae........ 
9 Fenograma resultante do alinhamento das seqüências ITS1 - 5.8S - ITS2 DNAr de diferentes espécies de M. anisopliae e B. bassiana.

10 Gradiente de temperatura entre 40 e $55^{\circ} \mathrm{C}$ para teste de especificidade para $M$. anisopliae com o par de primers ITSMet/ITS4

11 Amplificação com o par de primers ITS14/ITS4 para teste de especificidade entre as linhagens $\mathrm{E}_{9}$ e 14 de $M$. anisopliae e DNA do inseto sadio

12 Teste de amplificação com DNAs extraídos de insetos infectados utilizando-se os primers ITSMet/ITS4 e ITS14/ITS4

13 Digestão dos produtos de amplificação gerados com o par de primers ITSMet/ITS4 com endonucleases de restrição.

14 Digestão dos produtos de amplificação gerados com os primers ITSMet/ITS4 com diferentes endonucleases de restrição

15 Digestão dos produtos de amplificação gerados com o par de primers ITSMet/ITS4 com diferentes endonucleases de restrição.

16 Digestão dos produtos de amplificação gerados com o par de primers ITS14/ITS4 com diferentes endonucleases de restrição 


\section{LISTA DE TABELAS}

Página

1 Linhagens utilizadas no presente estudo............................................ 16

2 Oligonucleotídeos iniciadores utilizados no estudo.............................. 23

3 Perfil de restrição obtido a partir da digestão dos fragmentos de DNA correspondentes ao gene ribossômico

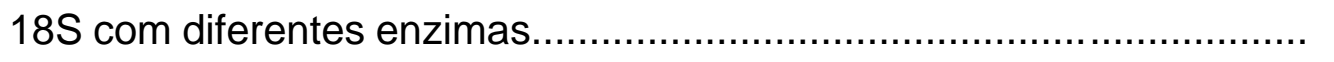

4 Perfil de restrição obtido a partir da digestão dos fragmentos de DNA, correspondentes àregião intergênica,

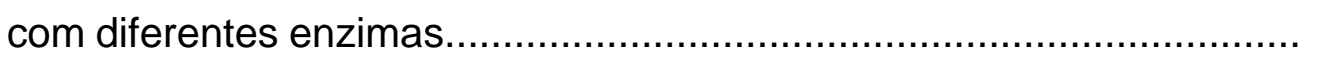




\title{
DETECÇÃO E IDENTIFICAÇÃO DE Metarhizium anisopliae EM LARVAS DE Diatraea saccharalis POR PRIMERS ESPECÍFICOS
}

\author{
Autor: RICARDO HENRI RODRIGUES DESTÉFANO \\ Orientador: Prof. Dr. CLAUDIO LUIZ MESSIAS
}

\section{RESUMO}

A região espaçadora ITS rDNA tem sido utilizada como uma importante ferramenta molecular para a identificação de fungos. Neste estudo a região ITS1 - 5.8S - ITS2 foi analisada em diferentes espécies do fungo entomopatogênico Metarhizium incluindo $M$. anisopliae, $M$. album e $M$. flavoviride com o objetivo de se construir primers específicos para a detecção e identificação do fungo no interior de larvas infectadas de Diatraea saccharalis. A amplificação desta região produziu um fragmento único de aproximadamente $540 \mathrm{pb}$ para as linhagens $\mathrm{E}_{9}, \mathrm{~B} / \mathrm{Vi}$ e $\mathrm{C}$, e de $600 \mathrm{pb}$ para a linhagem $14 \mathrm{de} \mathrm{M}$. anisopliae var. anisopliae; de 650 bp para M. album e 600 pb para M. flavoviride. Os produtos de PCR obtidos foram digeridos com diferentes enzimas de restrição Afa I, Alu I, Dde I, Hae III, Hpa II e Sau 3A I; e os perfis de PCR-RFLP mostraram nítidas diferenças entre as espécies analisadas. O sequenciamento da região ITS1 - 5.8S - ITS2 permitiu o desenho de primers específicos para as linhagens de M.a. var. anisopliae do Brasil e da Austrália. A amplificação não ocorreu em linhagens de $M$. álbum, M. flavoviride e Beauveria bassiana. Os DNAs extraídos de larvas infectadas pelas linhagens $E_{9}$, B/Vi e C do Brasil e linhagem 14, da Austrália, foram testados utilizando-se os primers 
desenvolvidos. Em todos os experimentos o fungo M.a. var. anisopliae foi detectado 48 horas após a inoculação. A técnica molecular empregada neste estudo permite a rápida e segura detecção e identificação de M.a. var. anisopliae em bioensaios de laboratório e de campo, programas de manejo de pragas e estudos de epizootiologia. 


\title{
DETECTION AND IDENTIFICATION OF Metarhizium anisopliae WITHIN INFECTED SUGARCANE BORER Diatraea saccharalis LARVAE USING SPECIFIC PRIMERS
}

\author{
Author: RICARDO HENRI RODRIGUES DESTÉFANO \\ Adviser: Prof. Dr. CLAUDIO LUIZ MESSIAS
}

\section{SUMMARY}

The ITS rDNA have been used as an important molecular tool for fungi identification. In this study the ITS1 - 5.8S - ITS2 rDNA regions were analyzed in different species of the entomopathogenic fungus Metarhizium including $M$. anisopliae, M. album and M. flavoviride, in order to construct specific primers for their detection and identification within infected Diatraea saccharalis larvae. The amplification of this region yielded a unique fragment of approximately $540 \mathrm{bp}$ for $\mathrm{E}_{9}, \mathrm{~B} / \mathrm{Vi}$ and $\mathrm{C}$, and $600 \mathrm{bp}$ for strain 14 of $\mathrm{M}$. anisopliae var. anisopliae; of $650 \mathrm{bp}$ for $M$. album and $600 \mathrm{bp}$ for M. flavoviride. The PCR products were digested with the different restriction endonucleases Afa I, Alu I, Dde I, Hae III, Hpa II and Sau 3A I; and the PCR-RFLP profiles showed clear differences amongst the species. The sequencing of the ITS-5.8S rDNA regions allowed for the design of specific primers for $M$. anisopliae var. anisopliae. The amplification was not observed with $M$. album, $M$ flavoviride and Beauveria bassiana strains. DNAs extracted fom infected larvae by $E_{9}$ and $C$ strains from Brazil and the strain 14 from Australia in individual bioassays were tested using previously designed specific primers. In all experiments, the fungus was detected after 48 
hours of post-inoculation. This molecular technique allows a fast and secure detection and identification of the entomopathogen in bioassays, in pest management programs and epizootiology. 


\section{INTRODUÇÃO}

A crescente preocupação com o meio ambiente tem ressaltado a importância das pesquisas científicas que procuram diminuir a agressão constante que o ecossistema vem sofrendo por intervenção do próprio homem. Por esse motivo e outros como alto custo dos defensivos agrícolas e aumento da resistência das pragas a estes produtos existentes no mercado, o número de pesquisas envolvendo organismos capazes de promover o controle biológico de pragas agrícolas e de interesse na saúde pública tem aumentado muito. Entre estes organismos, destacam-se alguns microrganismos que são agentes naturais de controle destas pragas, podendo ser manipulados em laboratórios e/ou em escala industrial.

As limitações inerentes à maioria dos inseticidas químicos em controlar as populações de insetos indesejáveis fizeram esse interesse crescer (Roberts, 1989). Os fungos foram os primeiros patógenos de insetos a serem utilizados no controle microbiano (Alves, 1998). Dentro deste quadro destacam-se alguns gêneros: Aschersonia, Aspergillus, Beauveria, Entomophthora, Erynia, Hirsutella, Metarhizium, Nomuraea, Paecillomyces e Verticillium.

O potencial de uso de fungos para controle biológico de pragas foi percebido por Metschnikoff (1879) e Krassilstschic (1888) que produziram Metarhizium anisopliae em larga escala para o controle da praga do trigo Anisopliae austriaca e de um curculionídeo da beterraba, Cleonus punctiventris.

Cerca de $80 \%$ das doenças dos insetos têm como agentes etiológicos os fungos pertencentes a cerca de 90 gêneros e mais de 700 espécies (Alves, 1986). 
A entomopatogenicidade, definida como a capacidade de produzir doença em insetos, depende de uma sequência de eventos de ordem mecânica e bioquímica que ocorrem de forma sincronizada pela deposição do conídio sobre a cutícula do inseto (adesão), seguida pela germinação, penetração, colonização, exteriorização das estruturas fúngicas e produção de esporos sobre a carcaça do hospedeiro (St.Leger et al., 1991b).

O deuteromiceto Metarhizium anisopliae é um importante agente microbiano utilizado no controle biológico. Sua ação é bastante conhecida e sua distribuição é global, ocorrendo em diferentes regiões, desde ambientes de clima temperado até clima tropical.

Para se avaliar a eficiência do fungo como agente microbiano de controle de pragas é necessária a realização de bioensaios com o inseto-alvo, e a recuperação do patógeno com o re-isolamento do mesmo após a morte do hospedeiro, o que demanda tempo.

Em ensaios de campo, é necessário o monitoramento da ação da linhagem do fungo sobre a população de insetos-alvo, podendo-se avaliar simultaneamente a atividade entomopatogênica de diferentes gêneros numa mesma área agrícola ou similar. Em bioensaios competitivos, situação na qual os insetos podem ser tratados com mais de uma linhagem do fungo ao mesmo tempo, a recuperação do patógeno deve ser seguida por outros procedimentos para a identificação da linhagem que foi eficiente.

A persistência e o impacto de linhagens do fungo introduzidas no meio ambiente, incluindo seus efeitos sobre hospedeiros não-alvos são fatores de grande importância e preocupação. Esta preocupação é exacerbada pela dificuldade de monitorar a dispersão e o estabelecimento do fungo quando liberado em condições de campo. Sendo $M$. anisopliae cosmopolita, são requeridas técnicas as quais possam distinguir entre linhagens nativas (autóctones) e introduzidas. Estas técnicas devem permitir que um grande número de amostras seja analisado com precisão e segurança, e de forma padronizada. Dessa forma, para determinar a eficácia de linhagens aplicadas e 
seus efeitos no meio ambiente, técnicas especiais são necessárias para detectar a presença do fungo dentro dos insetos coletados no campo (Leal et al., 1997).

Um estudo detalhado dessa natureza, melhora a compreensão sobre a distribuição do entomopatógeno e o desenvolvimento da sua epizootia em populações de insetos em nível micro-ambiental e regional (Thomsen \& Jensen, 2002).

Avanços na tecnologia molecular mostram grande potencial para a rápida detecção e identificação de fungos para propósitos médicos, científicos, agrícolas e comerciais. Numerosos alvos dentro do genoma de fungos têm sido avaliados em muitos trabalhos recentes, usando áreas da sequência dentro do DNA ribossomal (DNAr) (Rakotonirainy et al., 1994; Fouly et al., 1997; Driver et al., 2000; Anderson et al., 2001; Uetake et al., 2002). Esta região do genoma inclui os genes $18 \mathrm{~S}, 5.8 \mathrm{~S}$ e $28 \mathrm{~S}$ os quais codificam para RNA ribossomal (RNAr) e que tem uma sequência relativamente conservada de nucleotídeos entre os fungos. Também se incluem áreas variáveis da sequência de DNA chamadas ITS (internal transcribed spacer). Embora não traduzida dentro de proteínas, as ITS codificam regiões que têm um papel crítico no desenvolvimento do RNAr funcional, com variações na sequência entre espécies, mostrando-se muito promissoras como "regiões-assinatura" para ensaios moleculares.

A aplicação de técnicas moleculares em bioensaios pode permitir uma maior agilidade na detecção e identificação do patógeno infectante levando a um diagnóstico precoce da micose no inseto.

O objetivo deste trabalho foi o de desenvolver primers específicos para a rápida detecção e identificação do fungo entomopatogênico Metarhizium anisopliae dentro de insetos hospedeiros a partir de análises da região ITS1 $5.8 S-$ ITS2. 


\section{REVISÃO DE LITERATURA}

\subsection{O Fungo Metarhizium anisopliae (Metsch.) SOROKIN}

Baseando-se na morfologia e na produção de conídios, três espécies de Metarhizium são identificadas: $M$. anisopliae (Metsch.) Sorokin, M. flavoviride (Gams; Rozsypal) e M. album (Petch), sendo todas, potenciais agentes de controle microbiano de pragas de interesse agrícola e em saúde pública (Onofre et al., 2002).

A espécie M. anisopliae é composta por M. anisopliae var. anisopliae e M. anisopliae var. majus, entretanto, estudos recentes, baseados em sequências do gene ribossomal $28 \mathrm{~S}$ e região espaçadora ITS, sugerem duas novas variedades, M.a. var. lepidiotum e M.a. var. acridum (Driver et al., 2000).

M. flavoviride apresenta duas variedades que são reconhecidas baseando-se na dimensão conidial: M. flavoviride var. minus Rombach, Humber \& Roberts e M. flavoviride var. flavoviride Gams \& Rozsypal.

O deuteromiceto Metarhizium anisopliae pertence à ordem Hypocreales, família mitosporic Clavicipitaceae e foi descrito por Metschnikoff em 1879 pela primeira vez como Entomophtora anisopliae. O primeiro trabalho de controle microbiano realizado por este pesquisador, foi para o controle de larvas de Anisopliae austriaca, sendo finalmente classificado por Sorokin em 1883 como Metarhizium anisopliae. Desde então, a utilização e ação deste patógeno vêm sendo estudadas sobre muitas espécies de insetos. 
O potencial de uso de fungos para controle biológico de pragas foi sugerido por Metschnikoff (1879) e Krassilstschic (1888) que produziram Metarhizium anisopliae em larga escala para o controle da praga do trigo Anisopliae austriaca e de um curculionideo da beterraba Cleonus punctiventris.

Veen (1968) já apontara este fungo como um agente de controle biológico $œ m$ grandes potencialidades, tendo como hospedeiros mais de 200 espécies de insetos.

Metarhizium anisopliae apresenta geralmente conídios uninucleados (Tinline \& Noviello, 1971), com pequena proporção de binucleados (Luna, 1985; Bagagli, 1987). Luna \& Azevedo (1985) estudando várias linhagens de $M$. anisopliae, obtiveram indicações de que a grande variação na forma e tamanho de conídios parece ser característica do gênero, não se relacionando tão estritamente às condições de cultura.

Este fungo apresenta processo de heterocariose, o qual foi descrito por Tinline \& Noviello (1971), sendo que o processo parassexual completo, com obtenção de diplóides e segregantes, foi descrito por Messias (1979), Messias \& Azevedo (1980) e Al-aidroos (1980). Silveira (1983) obteve protoplastos de M. anisopliae e fusão entre protoplastos de mutantes morfológicos e auxotróficos. A separação de cromossomos do fungo pode ser verificada por meio da utilização da técnica de eletroforese em campo pulsado (PFGE - "Pulsed Field Gel Eletrophoresis") (Cordeiro, 1996).

M. anisopliae é um fungo de cultivo simples, necessitando quase que exclusivamente de uma fonte nutricional à base de amido; é cosmopolita, e sem dúvida é um dos fungos mais estudados em programas de manejo de pragas, uma vez que representa grande potencialidade como entomopatógeno (Onofre et al., 2002). 


\subsection{Patogenicidade e Virulência}

Segundo Fuxa \& Tanada (1987), a patogenicidade está mais relacionada a grupos ou espécies de patógenos, sendo uma característica "qualitativa", enquanto virulência determinaria o grau desta patogenicidade dentro de um grupo de espécies ou patógenos, caracterizando um termo "quantitativo".

Uma visão global da relação patogênica de fungos e insetos hospedeiros foi relatada nos trabalhos de Roberts (1989) e Messias (1989). Os autores resumem a importância, o estado de desenvolvimento e as formas de ação dos fungos entomopatogênicos, onde diferentes gêneros e espécies de fungos são citados.

O fungo M. anisopliae apresenta grande variabilidade natural. Vários trabalhos foram realizados com o objetivo de selecionar isolados para o controle de pragas como o cupim de montículo em pastagens, pragas de grãos armazenados e larvas de escarabeídeos que atacam a cana-de-açúcar, cigarrinha da cana, Mahanarva posticata (Alves, 1998).

A sua patogenicidade também tem sido verificada com elevada eficiência no controle de fêmeas ingurgitadas do carrapato Boophilus microplus (Onofre et al., 2002).

Segundo Fargues et al. (1975), o fungo M. anisopliae apresenta patogenicidade à 204 espécies de insetos pertencentes a 43 famílias dentre as ordens Orthoptera, Dermaptera, Hemiptera, Lepidoptera, Diptera, Hymenoptera Coleoptera, Homoptera e outras.

$O$ desenvolvimento da doença em insetos pode ser relacionado com a germinação do conídio, penetração através da cutícula por ação mecânicoenzimática, invasão, colonização do corpo do inseto e produção de toxinas.

O contato do conídio com o inseto hospedeiro marca o início da doença; o conídio germina sobre a cutícula do inseto e penetra através do integumento. Uma estrutura denominada apressório é responsável pela fixação do fungo sobre o inseto e posterior penetração (Madelin, 1966; Roberts \& Yendol, 1971). 
Forças físicas, pressão mecânica e produção de exoenzimas estão envolvidas no mecanismo de penetração do fungo; assim, a habilidade dos fungos entomopatogênicos em produzir certas enzimas extracelulares ou exoenzimas como protease, lipase e quitinase, estaria relacionada à penetração do fungo no integumento do hospedeiro e ao processo de colonização (Balfour-Browne, 1960; Ferron, 1978 e Rosato et al., 1981).

Os eventos de penetração de $M$. anisopliae no hospedeiro podem ser resumidos na formação de um apressório (extremidade dilatada da hifa com alta atividade secretora enzimática, que permite a penetração da epicutícula), penetração da pro-cutícula (também mecânico-enzimática) e formação de células com abundância de nutrientes armazenados (clamidósporo) que parece manter a viabilidade do fungo no corpo do hospedeiro por longos períodos até a esporulação superficial (Zacharuch 1970 a,b,c, e 1973).

Imediatamente após o contato, tubos germinativos crescem extensivamente através da procutícula após a germinação do conídio, com a formação de apressórios. Conídio, tubo germinativo e apressório são geralmente fundidos em estruturas de infecção de variados tamanhos e arranjos (Schabel, 1978).

Estudos de microscopia eletrônica revelaram importantes detalhes do modo de infecção de Heliothis zea por Beauveria bassiana, evidenciando que a invasão do corpo do hospedeiro ocorre também pelos espiráculos (Pekrul \& Grula, 1979).

Além da resistência mecânica, a cutícula também pode oferecer uma resistência química através de substâncias nela presentes que exercem ação inibitória sobre o fungo (Messias \& Pupin, 1990).

Messias \& Pupin (1990) relataram que lipídeos presentes na epicutícula de Diatraea saccharalis, entre eles os ácidos caprílico e capróico, inibem o crescimento de $M$. anisopliae. Substâncias com atividade inibidora sobre proteases de $M$. anisopliae foram isoladas de insetos por Kucera (1984). Atualmente os estudos sobre a ação de enzimas degradadoras, bem como os 
mecanismos envolvidos, se encontram num estágio de elucidação bastante desenvolvido (St. Leger et al., 1986c; 1992; 1993; Leite, 1987; Braga et al., 1998; Aguiar, 1990; Silva, 1985).

Entre as enzimas estudadas em M. anisopliae, amilase, lipase, protease e quitinase, a protease (Pr1) parece ser a mais ativa na penetração do hospedeiro (St. Leger et al., 1992).

Apesar de vários autores haverem estabelecido uma correlação positiva entre a produção de exoenzimas e o processo de penetração dos fungos entomopatogênicos em diversos hospedeiros, alguns resultados conflitantes foram obtidos quando se considerou a virulência das linhagens (Silva, 1985; Leite \& Messias, 1984; Leite, 1987; Aguiar, 1990; Paris \& Ferron, 1979; Pekrul \& Grula, 1979; Cheung \& Grula, 1982).

Toxinas produzidas por fungos entomopatogênicos têm sido descritas como associadas à morte do hospedeiro. Vários compostos tóxicos foram isolados e identificados de culturas de Beauveria, Cordyceps, Entomophthora, Metarhizium e Paecilomyces. Destruxinas A, B, C e D e dimetildestruxina B foram isoladas de culturas de $M$. anisopliae. Beauvericina foi encontrada em $B$. bassiana e $P$. farinosus. Cordicepina foi isolada de Cordyceps militaris e outras substâncias tóxicas não identificadas foram relatadas em espécies entomógenas de Aspergillus (Ferron; 1978).

Estudos sobre a produção de toxinas por fungos entomopatogênicos têm sido relatados por Roberts (1966, 1966a, 1969), Al-Aidroos \& Roberts (1978), Fargues et al. (1975), Kaijiang \& Roberts (1986), Lugli (1987), entre outros.

Silva \& Messias (1986) realizando bioensaios com o inseto Rhodnius prolixus, verificaram que mutantes de $M$. anisopliae que deixaram de produzir lipases e amilases, tiveram virulência menor que a das linhagens selvagens, enquanto que mutantes para a produção de proteases, não apresentaram níveis de virulência significativamente diferentes dos níveis das linhagens selvagens. Além disto, linhagens revertentes para a produção das duas primeiras enzimas tiveram seus níveis de virulência restaurados, concluindo os 
autores que a virulência das linhagens se altera quando ocorrem modificações na produção de enzimas.

Segundo Alves (1998) os principais projetos de controle de pragas envolvendo Metarhizium anisopliae no Brasil envolvem o controle de: cigarrinha-da-cana (Mahanarva posticata, M. fimbriolata); cigarrinha-daspastagens (Deois flavopicta, Zulia entreriana); cupim das pastagens (Cornitermes cumulans); cupim da cana-de-açúcar (gên. Heterotermes); brocada-bananeira (Cosmopolites sordidus); broca-dos-citros (Diploschema rotundicolle); percevejo-do-colmo do arroz (Tibraca limbativentris) e a broca-docafé (Hypothenemus hampei).

Além de $M$. anisopliae, $M$. flavoviride também tem sido reconhecido nos últimos tempos como um eficaz agente controlador de gafanhotos e outros insetos, pois, isolados desta espécie apresentam virulência elevada, resistência à altas temperaturas e podem ainda ser facilmente produzidos em condições laboratoriais (Onofre et al., 2002), sendo atualmente utilizado em grande escala na África e EUA.

\subsection{Marcadores moleculares}

As técnicas de diagnóstico molecular foram inicialmente utilizadas na taxonomia de microrganismos e têm sido intensamente aplicadas em programas de melhoramento genético. O objetivo dessas técnicas é revelar a variabilidade em nível de DNA e, conseqüentemente, detectar diferenças entre indivíduos (Marques et al., 2002).

A técnica de PCR ("Polymerase Chain Reaction") utiliza a característica das DNA polimerases de sintetizar moléculas de DNA, usando um molde de DNA de fita simples a partir de uma reação de dupla fita obtida, utilizando oligonucleotídeos sintéticos (primers). Essa técnica causou um enorme impacto na Biologia Molecular, inicialmente , e depois em várias outras áreas sendo 
uma das principais o diagnóstico de agentes infecciosos de maneira rápida e específica (Schrank \& Vainstein, 2002).

Muitos trabalhos científicos que utilizam esta técnica, diretamente ou de técnicas dela derivadas, têm sido publicados desde a sua descrição. Estes trabalhos têm permitido avanços significativos tanto em áreas básicas, como aquelas que buscam o entendimento de processos biológicos tundamentais, como em áreas aplicadas, dentre as quais a identificação de genótipos, o diagnóstico de doenças, estudos filogenéticos e melhoramento genético de plantas, animais e microrganismos (Anderson \& Stasovski, 1992; Ouellet \& Seifert, 1993). A facilidade, rapidez, versatilidade e sensibilidade desta técnica tornaram-na uma poderosa ferramenta em estudos genéticos que envolvem um grande número de organismos vivos (Ferreira \& Grattapaglia, 1996).

Por ser a PCR uma técnica simples, pouco tempo após sua descrição, diversos pesquisadores estavam aptos a realizar experimentos empregando modificações no princípio original, de maneira a expandir consideravelmente a aplicação desta técnica (Foster et al., 1993).

A variabilidade genética do gênero Metarhizium foi detectada por vários autores através da análise de RAPD ("Random Amplified Polymorphism DNA") (Cobb \& Clarckson, 1993; Fegan et al., 1993; Bidochka et al., 1994; Leal et al., 1994; Tigano-Milani et al., 1995; Fungaro et al., 1996; Freire et. al., 2001 e Alves et. al., 2001). Esta técnica também foi utilizada para diferenciar espécies, variedades e isolados do gênero Hirsutella (Strongman \& Mackay, 1993; Mozes-Koch et al.,1995) assim como para diferenciar isolados em espécies do gênero Zoophtora (Hodge et al.,1995). Welsh \& McClelland (1990) realizaram a PCR com primers de sequências arbitrárias para obter fingerprintings genômicos e os autores puderam demonstrar que diferentes linhagens pertencentes a várias espécies de bactérias podiam ser diferenciadas através da comparação do polimorfismo nos fingerprintings genômicos.

A separação de linhagens de diferentes isolados brasileiros de $M$. anisopliae var. anisopliae , M. anisopliae var. majus e M. flavoviride em grupos 
fenéticos foi obtida por Tigano-Milani et al. (1995). Esses autores investigaram a variabilidade genética das linhagens e verificaram que os genótipos estão mais relacionados æ̀ espécies hospedeiras do que com a origem geográfica.

Freire et al. (2001) analisando cinco mutantes, e a linhagem selvagem de Metarhizium anisopliae que originou estes mutantes por radiação gama, detectaram diferenças entre a linhagem selvagem e os mutantes pela alta sensibilidade da técnica de RAPD, evidenciando polimorfismo nas amostras, com um coeficiente médio de similaridade de $75 \%$.

Uma grande limitação observada na técnica de PCR-RAPD, é que há muita suscetibilidade à contaminação (interferência) por DNA não alvo, e a mesma só pode ser realizada de modo seguro com DNA de culturas puras (Leal et al., 1997; Thomsen \& Jensen, 2002).

Análises de seqüências por meio de RFLP ("Restriction Fragment Lenght Polymorphism") é também uma outra ferramenta que pode ser utilizada nas análises de DNA. Variações no tamanho de fragmentos gerados por distintas amostras de DNA após clivagem com enzimas de restrição podem ser avaliados pela comparação entre o número e o tamanho dos fragmentos produzidos pela digestão do DNA com ou sem uma posterior etapa de hibridização com sondas marcadas (Marques et al., 2002).

Uma alternativa para a identificação e diferenciação de fungos envolve utilização de primers específicos.

Hegedus \& Khachatourians (1996a) utilizaram primers específicos, correspondentes a segmentos de DNA específicos de $B$. bassiana, para identificação e diferenciação deste fungo através das técnicas de PCR e SSCP (Single-Strand Conformation Polymorphism Analysis) em isolados deste entomopatógeno infectando Melanoplus sanguinipes (gafanhotos migratórios). O perfil de restrição dos produtos de PCR, sequenciamento, e SSCP permitiram a diferenciação positiva de um isolado particular de $B$. bassiana em relação a outros. 
A detecção deste fungo dentro de $M$. sanguinipes durante o processo de infecção usando PCR e hibridização foi conseguida pela utilização de sondas específicas previamente construídas. O fungo pode ser detectado no inseto, 5 dias após a inoculação. Neste estudo, foram testados 2 protocolos para obtenção de DNA com pureza suficiente para uma boa amplificação em PCR usando primers derivados de uma sonda específica de $B$. bassiana. O protocolo estabelecido foi então usado para detectar a presença do fungo dentro de insetos infectados, desde o dia 0 até $010^{\circ}$ dia após a inoculação, onde se observou a correspondência entre o aumento na quantidade de produto de PCR e o tempo de infecção. Este estudo permitiu um aumento na sensibilidade de detecção, quando do isolamento de PCR/DNA amplificável de insetos infectados por fungos (Hegedus \& Khacahtourians, 1996b).

Outro marcador molecular amplamente utilizado na identificação e diferenciação de espécies é o DNA ribossomal (DNAr). Os DNAr nos eucariotos estão presentes repetidas vezes, e cada unidade consiste de regiões codificadas para os genes RNAr 18S, 5.8S e 28S, e dois espaços internos (ITS 1 e ITS 2) que separam essas regiões. Cada unidade do DNAr é separada por um espaço intergênico (IGS). A unidade de DNAr apresenta componentes em sua sequência que envolve variações e podem ser usadas em estudos de sistemática para diferentes níveis taxonômicos (Fouly et al., 1997).

As regiões DNAr $18 \mathrm{~S}$ e $28 \mathrm{~S}$ são muito conservadas e podem ser utilizadas para diferenciação em nível de gênero e espécie (Berbee \& Taylor,1995; Gargas \& Depriest,1996). Por outro lado, as regiões espaçadoras ITS e IGS acumulam mais variabilidade, sendo mais utilizadas na diferenciação de espécies ou entre linhagens da mesma espécie (Ristaino et al.,1998; EsteveZarzoso et al., 1999).

Costa (1999) utilizou o gene 18S, 28S rDNA, a regiao espaçadora 18S28S e o gene histona H3-1 como marcadores moleculares para efetuar estudos taxonômicos em Neurospora spp.. Este estudo permitiu a identificação de isolados deste fungo provenientes do Estado do Maranhão e São Paulo. 
Diferenças quanto ao tamanho da região espaçadora IGS no fungo Pyrenophora gramínea, agente causador da doença da folha da cevada, permitiram a identificação de dois grupos dentro deste gênero. Os produtos IGS-PCR possuíam 3,8 e 4,4 kb (Pecchia et al., 1998).

Ristaino et al. (1998) estudaram um método rápido de identificação para seis grupos taxonômicos do patógeno de plantas Phytophtora utilizando a comparação visual dos padrões de bandas de restrição para as enzimas Rsa I, Msp I e Hae III. A digestão do produto ITS obtido com as enzimas de restrição revelou perfis diferentes dentre as espécies testadas possibilitando, em todos os casos, a diferenciação inter e infra-específica. Os isolados foram caracterizados anteriormente por métodos tradicionais, através de características morfológicas. Os métodos moleculares foram, segundo os autores, ferramentas rápidas e fáceis para a identificação de espécies economicamente importantes dentro desse gênero.

As técnicas de amplificação e posterior sequenciamento do gene $5.8 \mathrm{~S}$ com as regiões intergênicas (ITS 1 e ITS 2) também foram aplicadas para Metarhizium. A análise filogenética dos dados de sequenciamento mostrou que M. anisoplaie constitui um grupo monofilético, e M. flavoviride e $M$. album representam duas linhas evolucionárias separadas (Sosa-Gomez et al., 1998).

Essa mesma abordagem foi empregada em estudos com Pleurotopsis longinqua para análises de diferenciação genética entre isolados de três regiões geográficas diferentes através do perfil de restrição obtido da amplificação da região ribossomal ITS 1-5.8S-ITS 2. Após sequenciamento, os autores encontraram diferenças de apenas quatro pares de bases, sugerindo que esta distribuição distinta é evolutivamente recente (Hughes et al., 1998).

Anderson et al. (2002) utilizaram a técnica de RFLP para separar isolados do fungo Pisolithus onde a sequência ITS foi usada para refinar a distinção entre os agrupamentos filogenéticos encontrados.

Bindslev et al. (2002) utilizando a técnica de PCR in situ (ISPCR) conseguiram diferenciar espécies de fungos fitopatogênicos, de difícil 
isolamento pelas características próprias desse tipo de material, onde ocorre a presença de diferentes microrganismos da mesma espécie, tornando muito problemática sua separação e posterior cultivo para identificação precisa.

Pela técnica de RFLP-PCR da região ITS 2 e com o desenho de primers específicos, Thomsen \& Jensen (2002) conseguiram determinar in vivo diferenças em nível de espécie dentro do complexo de Entomophthora muscae em cadáveres de diferentes espécies de moscas, cujo gênero é de difícil distinção.

Os relatos descritos acima mostram o alto grau de sensibilidade e precisão das técnicas moleculares permitindo que fungos entomopatogênicos possam ser liberados no ambiente e facilmente monitorados com bastante segurança (Hegedus \& Khachatourians, 1996b). 


\section{MATERIAL E MÉTODOS}

\subsection{Linhagens}

No presente trabalho utilizou-se, em todos os experimentos, linhagens de M. anisopliae ( $\mathrm{E}_{9}, \mathrm{~B} / \mathrm{Vi}, \mathrm{C}$ e 14), M. flavoviride (204 e 209) e Beauveria bassiana (959, 2253 e 2629) pertencentes ao Banco de Germoplasma de Fungos Entomopatogênicos do Departamento de Genética e Evolução da UNICAMP. A linhagem de M. album (201) foi gentilmente cedida pela Dra. Miriam TiganoMilani/CENARGEN-EMBRAPA. As linhagens estão listadas na Tabela 1.

\subsection{Meios de cultivo}

Os meios de cultivo utilizados para a manutenção e crescimento das linhagens e as soluções de rotina foram preparados e esterilizados.

\subsubsection{Meio Mínimo (MMI)(Pontecorvo et al., 1953, modificado)}

$\mathrm{NaNO}_{3}$ (Nitrato de sódio)

$\mathrm{KCl}$ (Cloreto de potássio)

$\mathrm{MgSO}_{4} .7 \mathrm{H}_{2} \mathrm{O}$ (Sulfato de magnésio)

$0,52 \mathrm{~g}$

$\mathrm{KH}_{2} \mathrm{PO}_{4}$ (Fosfato monobásico potássio)

Glicose (ou Dextrose)

$\mathrm{FeSO}_{4} .7 \mathrm{H}_{2} \mathrm{O}$ (1\% em Água)

Traços (2 gotas/L)

$\mathrm{ZnSO}_{4}$ (1\% em Água)

Traços (2 gotas/L)

Água destilada

$1.000 \mathrm{~mL}$ 
Tabela 1. Linhagens de Metarhizium e Beauveria utilizadas no presente estudo.

\begin{tabular}{|c|c|c|}
\hline Linhagem & Hospedeiro & Origem \\
\hline \multicolumn{3}{|l|}{$\begin{array}{l}\text { M. anisopliae var. } \\
\text { anisopliae }\end{array}$} \\
\hline$E_{9}$ & $\begin{array}{l}\text { Deois flavopicta (Homóptera: } \\
\text { Cercopidae) }\end{array}$ & Espírito Santo, Brasil \\
\hline $\begin{array}{l}\text { B/Vi (mut. auxotrófico tiamina } \\
\text { de } E_{9} \text { ) }\end{array}$ & & *UNICAMP, Brasil \\
\hline C & $\begin{array}{l}\text { Mahanarva posticata (Homóptera: } \\
\text { Cercopidae) }\end{array}$ & Alagoas, Brasil \\
\hline 14 & desconhecido & Austrália \\
\hline \multicolumn{3}{|l|}{ Metarhizium álbum } \\
\hline 201 (**ARSEF 2082) & $\begin{array}{l}\text { Cofana spectra (Homoptera: } \\
\text { Cicadellidae) }\end{array}$ & Indonésia \\
\hline \multicolumn{3}{|l|}{ Metarhizium flavoviride } \\
\hline 204 (ARSEF 2024) & $\begin{array}{l}\text { Otiorhynchus sulcatus } \\
\text { (Coleoptera: Curculionidae) }\end{array}$ & França \\
\hline 209 (ARSEF 2133) & $\begin{array}{l}\text { Ceutorhynchusmacula alba } \\
\text { (Coleoptera: Curculionidae) }\end{array}$ & Tchecoslováquia \\
\hline \multicolumn{3}{|l|}{ Beauveria bassiana } \\
\hline ARSEF 959 & $\begin{array}{l}\text { Spodoptera frugiperda } \\
\text { (Lepdoptera: Noctuidae) }\end{array}$ & Paraná, Brasil \\
\hline ARSEF 2253 & $\begin{array}{l}\text { Autographa gamma (Lepdoptera: } \\
\text { Noctuidae) }\end{array}$ & França \\
\hline ARSEF 2629 & $\begin{array}{l}\text { Diatraea saccharalis (Lepdoptera: } \\
\text { Pyralidae) }\end{array}$ & Pernambuco, Brasil \\
\hline
\end{tabular}

*Universidade Estadual de Campinas, São Paulo, Brasil

${ }^{* *}$ Agricultural Research Service of Entomopathogenic Fungi 
Ajustou-se o pH para 6,8 com $\mathrm{NaOH} 2 \mathrm{~N}$ ou $\mathrm{HCl} 1 \mathrm{~N}$, e adicionou-se $15 \mathrm{~g}$ de ágar para meio sólido

\subsubsection{Meio Completo (MC) (Pontecorvo et al., 1953, modificado)}

Acrescentou-se ao Meio Mínimo:

Peptona

Extrato de levedura

$0,50 \mathrm{~g}$

Caseína hidrolisada

Solução de vitaminas

Ajustou-se o pH para 6,8. Para meio sólido, adicionou-se $15 \mathrm{~g}$ de ágar.

\subsubsection{Solução de Vitaminas:}

Ácido nicotínico

$100 \mathrm{mg}$

Ácido p-aminobenzóico

$10 \mathrm{mg}$

Tiamina (Aneurina)

$50 \mathrm{mg}$

Biotina

$0,2 \mathrm{mg}$

Piridoxina (Cloridrato)

$50 \mathrm{mg}$

Riboflavina

$100 \mathrm{mg}$

Água Destilada

$100 \mathrm{~mL}$

Estocou-se em frasco escuro, sob refrigeração.

\subsubsection{Meio de Arroz}

Arroz beneficiado tipo I

$50 \mathrm{~g}$

Água destilada

$40 \mathrm{~mL}$ 
3.3 Soluções e Tampões

EDTA 0,5M pH 8,0

EDTA

$372,24 \mathrm{~g}$

Água destilada

$1.000 \mathrm{~mL}$

Acertou-se o pH com $\mathrm{NaOH}$ em pastilhas.

Tris-HCl $\quad 1 M$

Tris

$121,14 \mathrm{~g}$

Água destilada

$1.000 \mathrm{~mL}$

Acertou-se o pH para 7,2 e 8,0 com HCl concentrado.

Tampão de Extração (Tris-HCl 10mM e EDTA 1mM)

Tris- $\mathrm{HCl} 1 \mathrm{M} \mathrm{pH} 8,0$

$10 \mathrm{~mL}$

EDTA 0,5M pH 8,0

$2 \mathrm{~mL}$

Água Milli-Q

q.s.p. $1.000 \mathrm{~mL}$

\section{Acetato de Sódio 3M pH 8,0}

Acetato de sódio tri-hidratado

$408.10 \mathrm{~g}$

Água destilada

q.s.p. $1.000 \mathrm{~mL}$

Tampão de Lise

Tris- $\mathrm{HCl} 1 \mathrm{M}$ pH 7,2

$0,5 \mathrm{~mL}$

EDTA 0,5M pH 8,0

$1,0 \mathrm{~mL}$

SDS $10 \%(\mathrm{v} / \mathrm{v})$

$3,0 \mathrm{~mL}$

BME 10\%(v/v)

$1,0 \mathrm{~mL}$

Água Milli-Q

$4,5 \mathrm{~mL}$ 


\section{Tampão Tris Acetato (50X)}

Tris base

$242,00 \mathrm{~g}$

Ácido acético glacial

$57,10 \mathrm{~mL}$

EDTA 0,5M pH 8,0

$100 \mathrm{~mL}$

\subsection{Obtenção de conídios para inoculação em meio líquido}

Os conídios do fungo foram obtidos pelo cultivo em Meio Completo sólido, em incubação à $28^{\circ} \mathrm{C}$ por 10 dias. Este material foi utilizado para inoculação em meio líquido adequado para produção de micélio.

\subsection{Obtenção do micélio utilizado para extração do DNA}

Para as extrações de DNA, os micélios do fungo foram obtidos pela inoculação dos respectivos conídios em frascos Erlenmeyers de 1 litro contendo $400 \mathrm{~mL}$ de Meio Mínimo líquido adicionado em 10\% (v/v) de Meio Completo líquido, incubados à28 ${ }^{\circ} \mathrm{C}$, sob agitação de $150 \mathrm{rpm}$, por 72 horas.

O conteúdo de cada frasco foi filtrado em papel de filtro (Inlab tipo 10) e lavado com água destilada esterilizada. O micélio obtido foi acondicionado em placas de Petri muito bem vedadas com parafilme, congelado à $-80^{\circ} \mathrm{C}$ e posteriormente liofilizado (Liofilizador VIRTIS Co.), sendo mantido após, à $80^{\circ} \mathrm{C}$ até o momento do uso.

\subsection{Hospedeiro}

O inseto hospedeiro utilizado no presente trabalho foi a Diatraea saccharalis, conhecida como a broca da cana-de-açúcar.

Foram utilizadas larvas de terceiro ínstar, cedidas periodicamente pelo Centro de Tecnologia da Copersucar, Piracicaba-SP. 


\subsection{Bioensaios}

Para os experimentos de bioensaios, os conídios foram crescidos em Meio de Arroz, à2 ${ }^{\circ} \mathrm{C}$ por 10 dias.

Os bioensaios foram realizados separadamente para cada linhagem em estudo, infectando-se os insetos com o patógeno por caminhamento durante 10 minutos, com um potencial de inóculo de $3,5 \times 10^{6}$ conídios por inseto. Os insetos foram colocados em placas plásticas com 24 células individuais, juntamente com alimentação natural de colmo de cana-de-açúcar em cubo. Os experimentos foram conduzidos de forma que, a cada 24 horas num total de 72 horas, foram capturados em torno de 48 insetos por tratamento. Os insetos foram sacrificados imediatamente por congelamento à $-20^{\circ} \mathrm{C}$ e posteriormente levados para $-80^{\circ} \mathrm{C}$, e nessa condição guardados em placas de Petri muito bem vedadas com parafilme, até a realização das extrações de DNA. Um grupo adicional foi mantido até a morte.

Larvas de $D$. saccharalis sadias, não infectadas pelo entomopatógeno foram mantidas nas mesmas condições citadas acima para extração de DNA e comparação como referência (controle).

\subsection{Preparação dos insetos após os bioensaios, para extração de DNA (lavagem)}

Os insetos coletados durante os bioensaios e guardados à- $-80^{\circ} \mathrm{C}$, foram cuidadosamente lavados, inicialmente (3) três vezes com hipoclorito de sódio à 2,5\% por 10 minutos com agitação moderada, depois lavados (3) três vezes com solução de Tween 80 à $0,1 \%(v / v)$, e por último, (3) três vezes em solução salina à $0,85 \%$, sendo então colocados sobre papel de filtro esterilizado para secar em fluxo laminar. 
Os insetos lavados, limpos e secos foram guardados em placas de Petri muito bem vedadas com parafilme e estocados à $-80^{\circ} \mathrm{C}$ para posterior extração de DNA.

Após as lavagens, uma alíquota de $0,1 \mathrm{~mL}$ de solução salina da última lavagem foi então inoculada, em meio de cultura completo em placa de Petri e mantida à $28^{\circ} \mathrm{C}$ para certificação da eficiência da lavagem externa do hospedeiro.

Um grupo de insetos lavados foi colocado sobre o mesmo meio de cultivo para confirmar a ocorrência de infecção.

\subsection{Extração de DNA em pequena escala}

Os insetos coletados no segundo dia, ou seja, após $48 \mathrm{~h}$ do início dos bioensaios foram macerados em almofariz com nitrogênio líquido para o procedimento de extração de DNA.

As extrações de DNA em pequena escala foram realizadas segundo a metodologia descrita por Gaber \& Yoder (1983). A um microtubo tipo Eppendorf de $1,5 \mathrm{~mL}$ foi adicionado micélio liofilizado e pulverizado em almofariz com auxílio de nitrogênio líquido. A quantidade de micélio foi de aproximadamente $60 \mathrm{mg}$. A seguir, foram adicionados $600 \mu \mathrm{L}$ de tampão de lise (TL), previamente aquecido, e a mistura foi incubada à $65^{\circ} \mathrm{C}$, por 1 hora. Terminado o período de incubação, foram adicionados $600 \mu \mathrm{L}$ de clorofórmio:fenol equilibrado (1:1). Posteriormente, a mistura foi submetida à centrifugação de $13.500 \mathrm{rpm}$ (microcentrífuga Eppendorf) por 15 minutos. A fase aquosa contendo o DNA foi transferida para um novo microtubo. A extração fenólica foi realizada por mais duas vezes. A seguir, foram adicionados $10 \mu \mathrm{L}$ de acetato de sódio $3 \mathrm{M}$ à fase aquosa, seguido da adição de 0,54 vezes o volume de isopropanol. $\mathrm{O}$ tubo foi mantido à $-70^{\circ} \mathrm{C}$ por 15 minutos. Após a precipitação do DNA, procedeu-se uma centrifugação à $12.000 \mathrm{rpm}$ por 3 minutos. O 
sedimento foi lavado com etanol $70 \%(\mathrm{v} / \mathrm{v})$ gelado por duas vezes. Após descarte do etanol, os tubos foram invertidos sobre papel absorvente e deixados secar por aproximadamente duas horas em estufa à $37^{\circ} \mathrm{C}$. O DNA foi suspenso em $100 \mu \mathrm{L}$ de tampão TE (10mM Tris-HCl, 0,1mM EDTA). Posteriormente, $4 \mu \mathrm{L}$ de RNAse (solução estoque de $2,5 \mathrm{mg} / \mathrm{mL}$ ) foram adicionados à solução de DNA e incubou-se em estufa à $37^{\circ} \mathrm{C}$ por uma hora. Após, a solução foi mantida em geladeira durante a noite.

Após este período, $20 \mu \mathrm{L}$ de cloreto de lítio $4 \mathrm{M}$ e $120 \mu \mathrm{L}$ de clorofórmioálcool isoamílico (proporção 24:1) foram adicionados. Misturou-se as fases manualmente. $O$ material foi centrifugado a $12.000 \mathrm{rpm}$ por 8 minutos para separar as duas fases. A fase aquosa foi transferida para um novo microtubo e adicionou-se $400 \mu \mathrm{L}$ de etanol absoluto. Misturou-se por inversão e centrifugou-se à $12.000 \mathrm{rpm}$ por 4 minutos. Descartou-se o sobrenadante. $\mathrm{O}$ sedimento foi lavado por 2 vezes com $500 \mu \mathrm{L}$ de etanol 70\%. Após secagem em estufa à $37^{\circ} \mathrm{C}$, o DNA foi suspenso em $100 \mu \mathrm{L}$ de tampão TE, e estocou-se em freezer à- $20^{\circ} \mathrm{C}$.

Esta mesma metodologia foi também utilizada para a extração de DNA dos insetos infectados e não infectados pelo fungo.

\subsection{Amplificação do DNA por PCR}

Os oligonucleotídeos iniciadores utilizados para amplificação do gene rDNA 18S e região intergênica ITS foram sintetizados pela GIBCO (Life Technologies) e encontram-se listados na Tabela 2. Eles foram suspensos em água Milli-Q esterilizada para concentração final de $200 \mu \mathrm{M}$. As soluções de trabalho foram utilizadas na concentração de 20 a $30 \mu \mathrm{M}$.

As amplificações de DNA foram realizadas em termociclador Perkin Elmer/PCR System 480 e MJ Research PTC 200. 
As reações de amplificação foram efetuadas em volumes de $25 \mu \mathrm{L}$ contendo: $10 \mathrm{mM}$ Tris- $\mathrm{Cl}$, $\mathrm{pH}$ 8,3; $100 \mathrm{mM}$ de uma mistura de dATP, dCTP, dGTP e dTTP (Amersham Biosciences); 0,4 mM do primer; 1Ul de Taq DNA polimerase (Genotaq) por reação, e $100 \mathrm{ng}$ do DNA molde. O programa de amplificação do gene $18 \mathrm{~S}$ das amostras consistiu de um ciclo de desnaturação inicial a $95^{\circ} \mathrm{C} / 3 \mathrm{~min}$.; seguido de 32 ciclos a $94^{\circ} \mathrm{C} / 1 \mathrm{~min}$.; $57^{\circ} \mathrm{C} / 1 \mathrm{~min}$. e $72^{\circ} \mathrm{C} / 2$ min; e um ciclo a $72^{\circ} \mathrm{C} / 3$ min. (extensão final). Para amplificação da região intergênica o programa foi de um ciclo de desnaturação inicial a $95^{\circ} \mathrm{C} / 3 \mathrm{~min}$.; seguido de 32 ciclos a $94^{\circ} \mathrm{C} / 1 \mathrm{~min}$; $50^{\circ} \mathrm{C} / 1 \mathrm{~min}$. e $72^{\circ} \mathrm{C} / 1 \mathrm{~min}$; e um ciclo a $72^{\circ} \mathrm{C} / 3$ min. (extensão final). Os produtos obtidos foram submetidos à eletroforese em gel de agarose 1,3\%/TAE 1X, corado com brometo de etídio (Maniatis et al., 1982), visualizados em fonte de luz U.V. e registrados pelo sistema de fotodocumentação digital Alpha Innotech 2200.

Tabela 2. Oligonucleotídeos iniciadores utilizados no estudo.

\begin{tabular}{ccccc}
\hline Primer & Sequência (5' para 3') & Região & No. pb & Referência \\
\hline NS1 & GTA GTC ATA TGC TTG TCT C & rDNA 18S & 19 & White et al.,1990 \\
NS8 & TCC GGA GGT TCA CCT ACG GA & rDNA 18S & 20 & White et al.,1990 \\
ITS1 & TCC GTA GGT GAA CCT GCG G & $\begin{array}{c}\text { região } \\
\text { intergênica }\end{array}$ & 19 & White et al.,1990 \\
ITS4 & TCC TCC GCT TAT TGA TAT GC & $\begin{array}{c}\text { região } \\
\text { intergênica }\end{array}$ & 20 & White et al.,1990 \\
& & &
\end{tabular}

\subsection{Digestão dos produtos de PCR com endonucleases de restrição}

Os produtos de PCR foram digeridos com as seguintes enzimas de restrição: Afa I, Alu I, Dde I, Hae III, Hpa II e Sau 3A I. Foram utilizados $3 \mu \mathrm{L}$ do produto gerado em reações de $15 \mu \mathrm{l}$ com $5 \mathrm{U}$ de enzima por reação. As 
condições de temperatura foram empregadas de acordo com as recomendações do fabricante (Amersham Biosciences).

A observação do perfil de restrição obtido foi realizada através de eletroforese em gel de agarose 3\%. Os géis foram corados com brometo de etídeo $(0,1 \mu \mathrm{g} / \mathrm{mL})$, visualizados em fonte de luz U.V. e registrados pelo sistema de fotodocumentação digital Alpha Innotech 2200.

\subsection{Análise dos padrões de fingerprinting}

Os perfis obtidos por PCR-RFLP da região ITS-5.8S DNAr foram analisados através do sistema binário bandas presentes (1) ou ausentes (0) para cada linhagem. Os fragmentos com peso molecular abaixo de 100 pb não foram considerados nas análises. A matriz de similaridade foi construída utilizando-se o programa de similaridade para dados qualitativos (SIMQUAL), com o coeficiente de Dice. Os dendrogramas foram construídos utilizando-se o algorítmo de agrupamento UPGMA (Unweighted Pair-Group Method with Arithmetic Mean) por meio do programa NTSYS-PC (Rohlf, 1992).

\subsection{Purificação dos produtos de amplificação para sequenciamento}

Os produtos de amplificação correspondentes à região ITS - 5.8S DNAr das linhagens de $M$. anisopliae var. anisopliae ( $\mathrm{E}_{9}, \mathrm{~B} / \mathrm{Vi}, \mathrm{C}$ e 14), M. album (201), M. flavoviride (204 e 209) e B. bassiana (959, 2253 e 2629) foram purificados utilizando-se o kit GFX PCR DNA and Gel Band Purification (Amersham Biosciences) de acordo com as recomendações do fabricante, para posterior sequenciamento.

Após as purificações, o DNA das diferentes linhagens foi quantificado em gel de agarose $1 \%$. 


\subsection{Sequenciamento da região ITS1 - 5.8S - ITS2 DNAr}

As reações para sequenciamento dos DNAs correspondentes à região ITS1 - 5.8S - ITS2 DNAr foram efetuadas por meio de PCR com o kit Big Dye (Perkin Elmer) utilizando-se o primer ITS 1 e a purificação da reação foi feita segundo o fabricante do kit. As amostras de DNA foram secas, suspensas em tampão apropriado e submetidas à eletroforese no seqüenciador automático, marca Perkin Elmer, modelo ABI Prism Model 377 (LGE/IB/UNICAMP).

\subsection{Análise filogenética}

As sequências obtidas neste estudo foram alinhadas com seqüências correspondentes à região ITS1 - 5.8S - ITS4 do DNAr de Metarhizium anisopliae (números de acesso AF 516295, AF 134150), M. album (no. acesso AF 137067), M. flavoviride (no. acesso AF 138269) e Beauveria bassiana (no. acesso BBA 345090), recuperadas da base de dados GenBank, utilizando-se o programa ClustalW. As análises filogenéticas foram efetuadas utilizando-se o programa GDE (gopher://megasun.bch.umontreal.ca:70/11/GDE). As matrizes de distância foram calculadas utilizando-se o método DNADIST e o parâmetro Kimura 2 de correção, implementado no programa PHYLIP V. 3.5 (Felsenstein, 1989). As árvores filogenéticas foram construídas utilizando-se o algoritmo baseado no método de Neighbor-joining (Saitou \& Nei, 1987).

\subsection{6 "Desenho" e Síntese dos oligonucleotídeos (primers) específicos}

As regiões selecionadas para o desenho de primers específicos foram analisadas por meio do programa Gene Runner versão 3.05 (http//www.generunner.com). A especificidade dos primers foi então confirmada por comparação com outras sequências disponíveis no banco de dados GenBank/EMBL/DDBJ. Posteriormente, esta especificidade foi confirmada em reações de PCR com gradiente de temperatura para se obter as condições ideais de amplificação. Os produtos obtidos foram visualizados em gel de agarose $1,4 \%$, corado com brometo de etídio. 


\section{RESULTADOS}

\subsection{Amplificação do gene 18S DNAr e da região ITS1 - 5.8S - ITS2 DNAr}

\subsubsection{Análise do gene 18S DNAr}

O potencial do gene ribossomal $18 \mathrm{~S}$ para diferenciação de Metarhizium em nível de espécie foi avaliado por meio de análises de RFLP ("Restriction Fragment Length Polymorphism"). Foram amplificados os DNAs genômicos das seguintes linhagens: $M$. anisopliae var. anisopliae ( $\mathrm{E}_{9}, \mathrm{~B} / \mathrm{Vi}, \mathrm{C}$ e 14), M. album (201), M. flavoviride (204 e 209) e B. bassiana (959, 2253 e 2629).

A amplificação com o par de primers NS1 e NS8 (Figura 1) resultou numa banda de aproximadamente 1.800 pares de bases (pb) somente para as linhagens pertencentes ao gênero Metarhizium, não ocorreu amplificação nas linhagens de Beauveria. Após a amplificação, os produtos obtidos foram submetidos às digestões com as enzimas de restrição Afa I, Alu I, Dde I, Hae III, Hpa II e Sau 3A I. O perfil de restrição obtido está demonstrado na Tabela 3 e as digestões com Afa I, Alu I, Dde I, Hae III estão ilustradas na Figura 2. A diferenciação entre as espécies deste gênero foi possível apenas com enzima Afa l. 


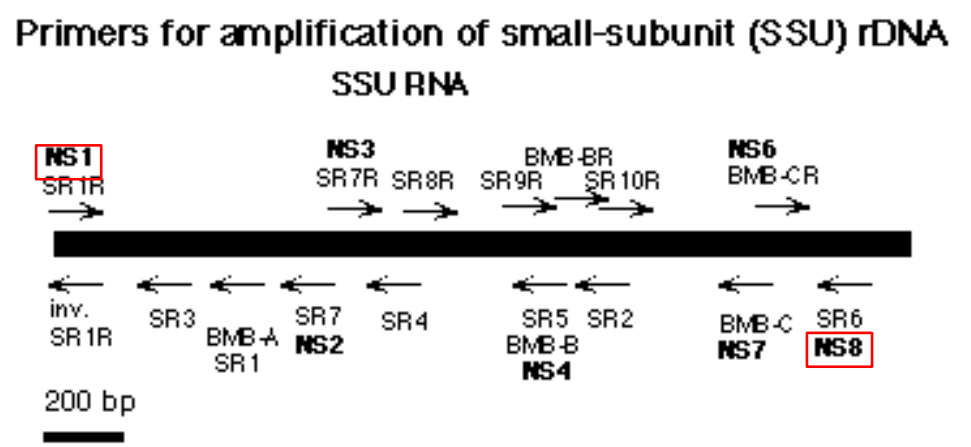

Figura 1 - Esquema do par de primers NS1 e NS8 da sub-unidade menor $18 \mathrm{~S}$.

Tabela 3. Perfil de restrição obtido a partir da digestão dos fragmentos de DNA correspondentes ao gene ribossômico $18 \mathrm{~S}$ com diferentes enzimas.

\begin{tabular}{|c|c|c|}
\hline Enzimas & Fragmentos em pares de bases & Linhagens \\
\hline Afa I & $\begin{array}{l}120,160,460,590,900 \\
120,160,590,900 \\
160,460,590 \\
150,170,400,1000\end{array}$ & $\begin{array}{l}\text { M. anisopliae: } \mathrm{E}_{9}, \mathrm{~B} / \mathrm{Vi}, \mathrm{C} \\
\text { M. anisopliae: } 14 \\
\text { M. album: } 201 \\
\text { M. flavoviride: } 204 \text { e } 209\end{array}$ \\
\hline Alu I & $\begin{array}{l}120,160,350,520,560,600 \\
120,140,160,350,520,560,600 \\
120,140,350,520,600\end{array}$ & $\begin{array}{l}\text { M. anisopliae: } \mathrm{E}_{9}, \mathrm{~B} / \mathrm{Vi} \\
\text { M. anisopliae: C, } 14 \\
\text { M. album: } 201 \text { e } \text { M. flavoviride: } 204 \text { e } \\
209\end{array}$ \\
\hline Dde I & $\begin{array}{l}100,200,310,350,500 \\
200,310,350,500 \\
240,320,900\end{array}$ & $\begin{array}{l}\text { M. anisopliae: } \mathrm{E}_{9}, \mathrm{~B} / \mathrm{Vi} \\
\text { M. anisopliae: C, } 14 \\
\text { M. album: } 201 \text { e M. flavoviride: } 204 \text { e } \\
209\end{array}$ \\
\hline Hae III & $\begin{array}{l}100,190,260,310,500 \\
190,260,310,500\end{array}$ & $\begin{array}{l}\text { M. anisopliae: } \mathrm{E}_{9}, \mathrm{~B} / \mathrm{Vi}, \mathrm{C} \\
\text { M. anisopliae: } 14 ; \text { M. album: } 201 \text { e } M \text {. } \\
\text { flavoviride: } 204 \text { e } 209\end{array}$ \\
\hline Hpa II & $\begin{array}{l}200,580,750,820 \\
200,750,820 \\
200,300,650\end{array}$ & $\begin{array}{l}\text { M. anisopliae: } \mathrm{E}_{9}, \mathrm{~B} / \mathrm{Vi}, \mathrm{C} \\
\text { M. anisopliae: } 14 \\
\text { M. album: } 201 \text { e M. flavoviride: } 204 \mathrm{e} \\
209\end{array}$ \\
\hline Sau 3A I & $\begin{array}{l}700,850 \\
700,900\end{array}$ & $\begin{array}{l}\text { M. anisopliae: } E_{9}, \mathrm{~B} / \mathrm{Vi}, \mathrm{C}, 14 \\
\text { M. album: } 201 \text { e M. flavoviride: } 204 \text { e } \\
209\end{array}$ \\
\hline
\end{tabular}




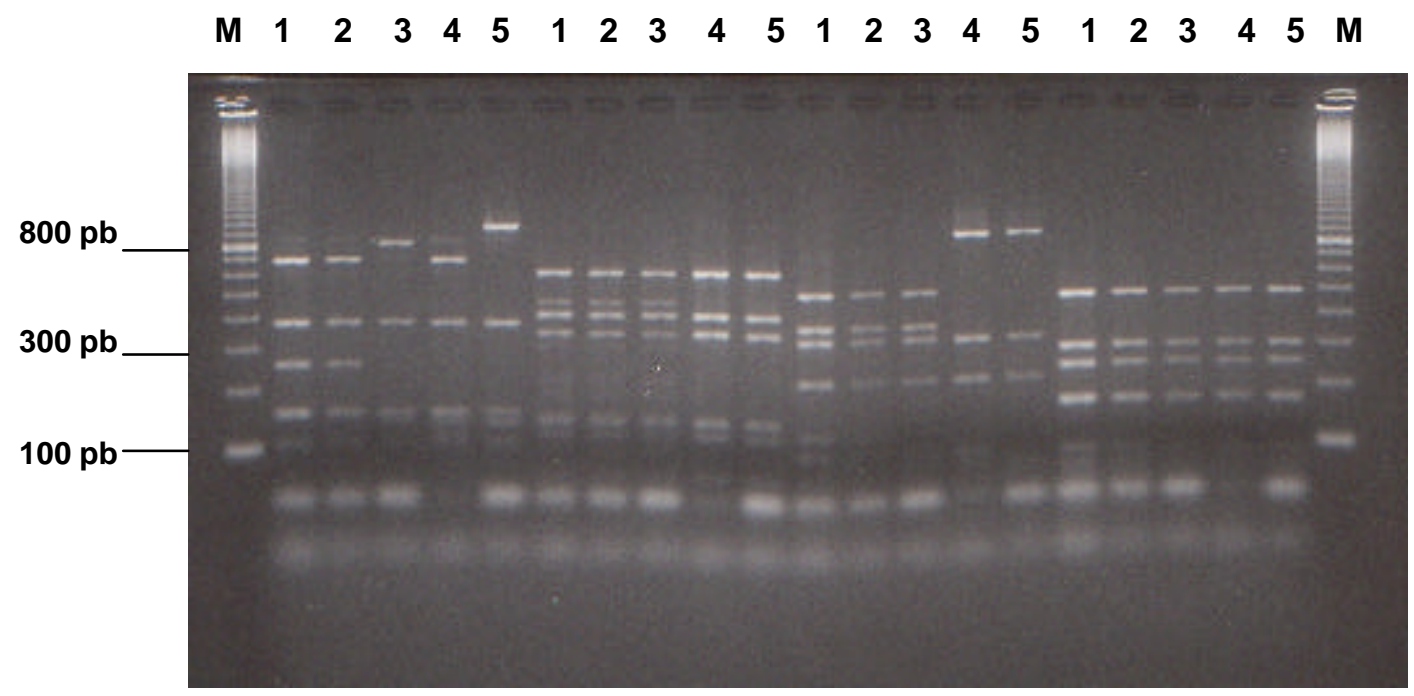

Figura 2 - Digestão do gene $18 \mathrm{~S}$ com Afa I, Alu I, Dde I e Hae III, (M) marcador de peso molecular de 100pb (Pharmacia). Metarhizium anisopliae (1) $\mathrm{E}_{9}$; (2) C; (3) 14; M. album (4) 201; M. flavoviride (5) 204.

\subsubsection{Análise da região ITS1 - 5.8S - ITS2}

A região ITS (Figura 3) também foi analisada nestas mesmas linhagens com o objetivo de se obter diferenciação clara entre as três espécies testadas, uma vez que nas análises do gene $18 \mathrm{~S}$ somente a digestão com a enzima Afa I permitiu distinguir $M$. anisopliae de $M$. album e M. flavoviride. A amplificação com o par de primers ITS1 e ITS4 resultou num fragmento de aproximadamente $540 \mathrm{pb}$ nas linhagens $\mathrm{E}_{9}, \mathrm{~B} / \mathrm{Vi}$, e C; de $600 \mathrm{pb}$ na linhagem 14 de $M$. anisopliae; de $650 \mathrm{pb}$ nas linhagens de $M$. album e de $600 \mathrm{pb}$ na linhagem de $M$. flavoviride. Os produtos de amplificação foram digeridos com Afa I, Alu I, Dde I, Hae III, Hpa II e Sau 3A I. O perfil de restrição obtido está demonstrado na Tabela 4 e ilustrado nas Figuras 4 e 5 . A diferenciação entre essas espécies foi possível com todas as enzimas testadas 


\section{ITS primers}

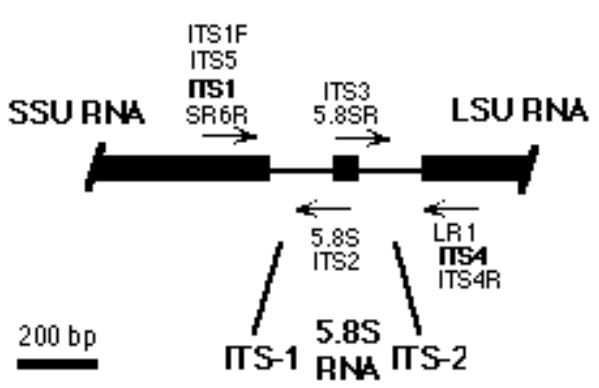

Figura 3.- Esquema dos primers utilizados para amplificação da região intergênica

Tabela 4. Perfil de restrição obtido a partir da digestão dos fragmentos de DNA, correspondentes àregião intergênica, com diferentes enzimas.

\begin{tabular}{lll}
\hline Enzimas & Fragmentos em pares de bases & Linhagens \\
\hline Afa I & 540 & M. anisopliae: $\mathrm{E}_{9}, \mathrm{~B} / \mathrm{Vi}, \mathrm{C}$ \\
& 100,500 & M. anisopliae: 14 \\
& 180,450 & M. album: 201 \\
Alu I & 600 & M. flavoviride: 209 \\
& 540 & M. anisopliae: $\mathrm{E}_{9}, \mathrm{~B} / \mathrm{Vi}, \mathrm{C}$ \\
& 200,400 & M. anisopliae: 14 \\
& 650 & M. album: 201 \\
Dde I & 100,450 & M. flavoviride: 204 e 209 \\
& 150,400 & M. anisopliae: $\mathrm{E}_{9}, \mathrm{~B} / \mathrm{Vi}, \mathrm{C}$ \\
& 180,430 & M. anisopliae: 14 \\
Hae III & 190,450 & M. album: 201 \\
& 160,450 & M. flavoviride: 204 e 209 \\
& 120,410 & M. anisopliae: $\mathrm{E}_{9}, \mathrm{~B} / \mathrm{Vi}, \mathrm{C}$ \\
& 130,450 & M. anisopliae: 14 \\
Hpa II & 100,410 & M. album: 201 \\
& 100,390 & M. flavoviride: 204 e 209 \\
& 100,360 & M. anisopliae: $\mathrm{E}_{9}, \mathrm{~B} / \mathrm{Vi}, \mathrm{C}$ \\
& 100,370 & M. anisopliae: 14 \\
& $100,120,250$ & M. album: 201 \\
& $100,160,340$ & M. flavoviride: 209
\end{tabular}


Tabela 4. Perfil de restrição obtido a partir da digestão dos fragmentos de DNA, correspondentes àregião intergênica, com diferentes enzimas.

\begin{tabular}{lll}
\hline Enzimas & Fragmentos em pares de bases & Linhagens \\
\hline Sau 3A I & $170,190,210$ & M. anisopliae: $\mathrm{E}_{9}, \mathrm{~B} / \mathrm{Vi}, \mathrm{C}$ \\
& $100,120,190,210$ & M. anisopliae: 14 \\
& 210 & M. album: 201 \\
& 180,410 & M. flavoviride: 209 \\
\hline
\end{tabular}

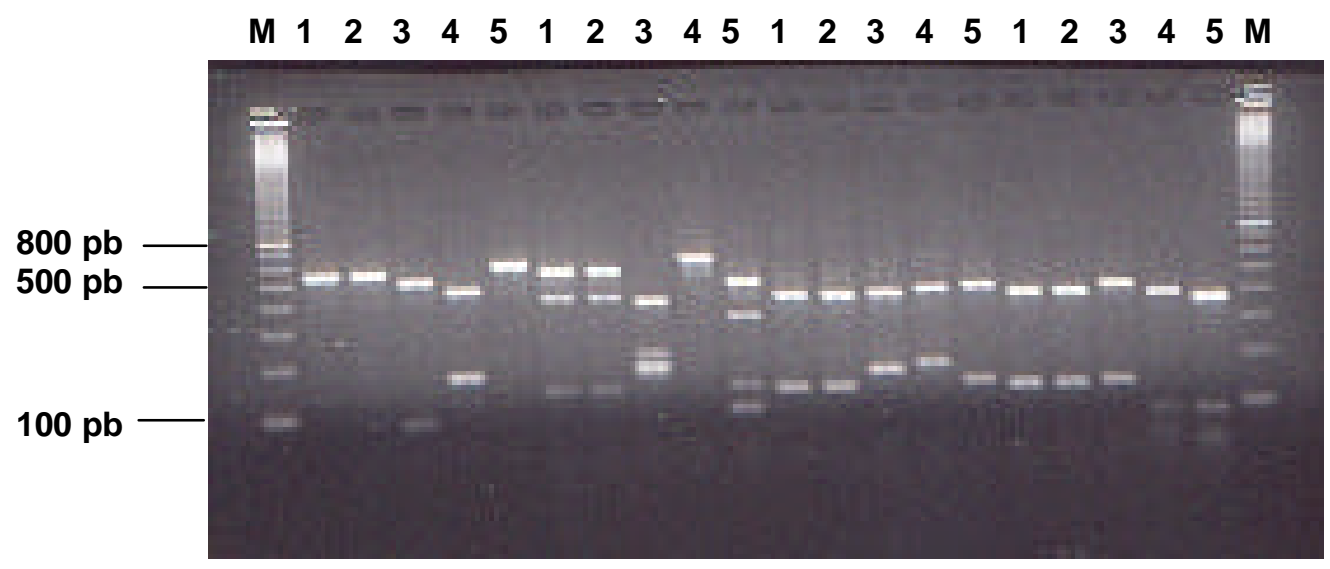

Figura 4 - Digestão da região espaçadora ITS com Afa I, Alu I, Dde I e Hae III, (M) marcador de peso molecular de 100pb (Pharmacia). Metarhizium anisopliae (1) Eg; (2) C; (3) 14; M. album (4) 201; M. flavoviride (5) 204. 


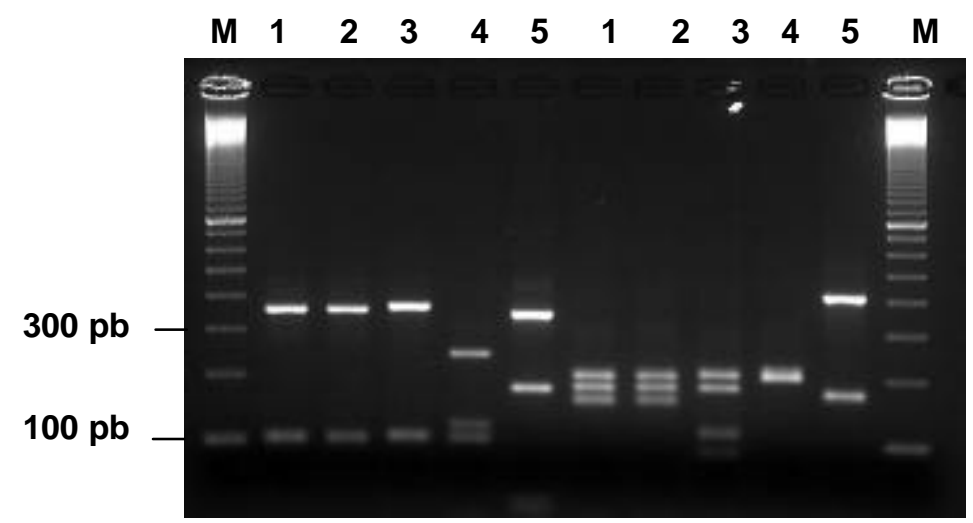

Figura 5 - Digestão da região espaçadora ITS com Hpa II e Sau 3A I. (M) marcador de peso molecular de 100pb (Pharmacia). Metarhizium anisopliae (1) $\mathrm{E}_{9}$; (2) C; (3) 14; M. album (4) 201;M. flavoviride (5) 204.

\subsubsection{Análise de PCR-RFLP da região ITS1 - 5.8S - ITS2}

Os resultados obtidos no PCR-RFLP das diferentes espécies de Metarhizium foram analisados para construção de uma matriz de similaridade utilizando-se o coeficiente de Dice. A linhagem de M.a. var. anisopliae B/Vi foi excluída desta análise por ser um mutante auxotrófico da linhagem $E_{9}$ que apresentou perfis idênticos à mesma. O dendrograma obtido revelou três grupos muito distintos: o grupo I compreendeu as linhagens de M.a. var. anisopliae $\mathrm{E}_{9}, \mathrm{C}$ e 14 sendo que as duas primeiras apresentaram $100 \%$ de similaridade entre si e apenas 33\% aproximadamente com a linhagem 14; o grupo II ficou representado pela linhagem 201 de $M$. album, com aproximadamente $24 \%$ de similaridade com a espécie de $M$. anisopliae; e o grupo III ficou composto pela linhagem 204 de M. flavoviride com apenas $5 \%$ de similaridade com as demais espécies (Figura 6). 


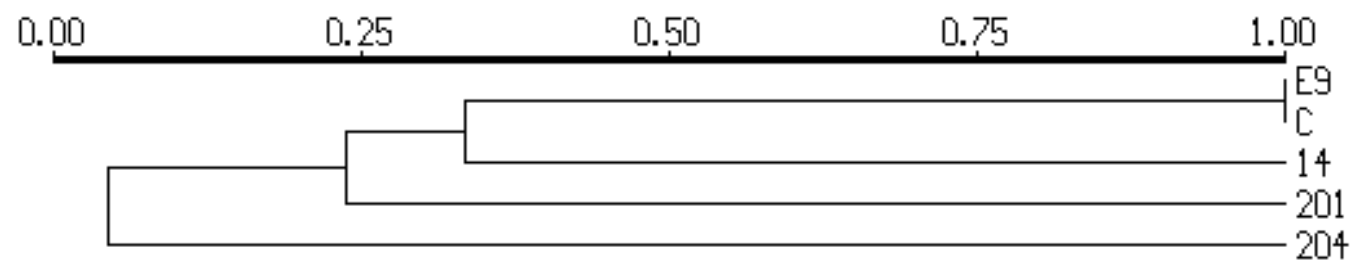

Figura 6 - Dendrograma de similaridade obtido com o coeficiente de Dice.

\subsection{Sequenciamento da região ITS1 - 5.8S - ITS2 DNAr de diferentes espécies de Metarhizium e Beauveria bassiana}

As diferenças detectadas na região ITS1 - 5.8S - ITS2 DNAr das linhagens de Metarhizium obtidas por PCR-RFLP indicaram a possibilidade de desenho de primers específicos desta região para a detecção e identificação de $M$. anisopliae. Linhagens de $M$. album, M. flavoviride e B. bassiana também foram incluídas. A quantidade de produto de amplificação da região nas linhagens de Beauveria foi inferior æ̀s outras linhagens, porém suficiente para o sequenciamento (Figura 7).

Após amplificação da região ITS1 - 5.8S - ITS2 DNAr das linhagens de M.a var. anisopliae (E9; BVi; C e 14); M. album (201); M. flavoviride (204 e 209) e Beauveria bassiana (959, 2253 e 2629), os produtos resultantes foram submetidos à eletroforese em gel de agarose para purificação dos fragmentos por meio de um kit de purificação.

Os produtos purificados e quantificados foram submetidos à eletroforese em sequenciador automático do Laboratório de Genômica do Departamento de Microbiologia e Genética da UNICAMP. Os dados das seqüências obtidas encontram-se no Anexo. 


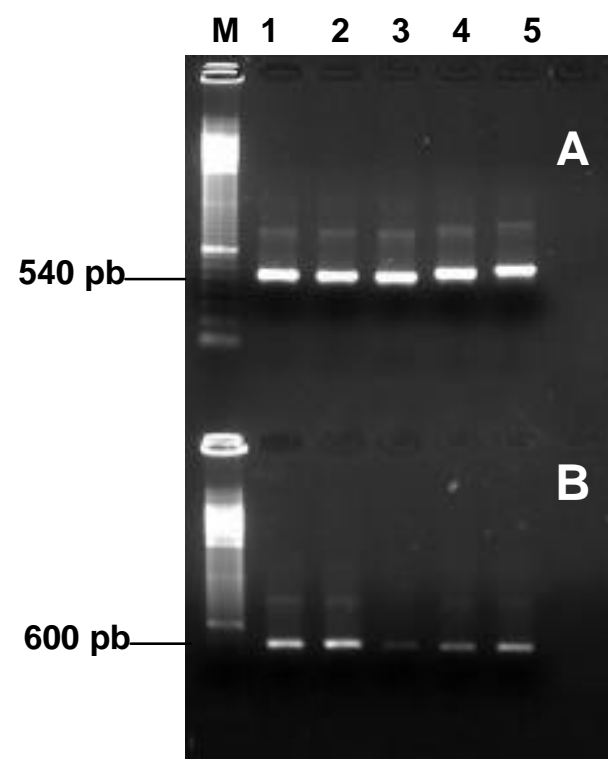

Figura 7 - Amplificação da região ITS em diferentes espécies de Metarhizium e Beauveria. (M) marcador de peso molecular de 100pb (Pharmacia). (A) Metarhizium anisopliae: (1) $\mathrm{E}_{9}$; (2) BVi; (3) C; (4) 14; M. album: (5) 201; (B) M. flavoviride (1) 204; (2) 209; Beauveria bassiana (3) 959; (4) 2253 e (5) 2629.

\subsection{Análise filogenética da região ITS1 - 5.8S - ITS2 do operon ribossômico}

Sequências correspondentes à região ITS1 - 5.8S - ITS4 do DNAr das linhagens do presente estudo foram comparadas com seqüências de $M$. anisopliae (números de acesso AF516295 e AF134150), M. album (no. acesso AF137067), M. flavoviride (no. acesso AF138269) e B. bassiana (no. acesso BBA345090), depositadas na base de dados GenBank. O alinhamento e análise filogenética destas sequências revelaram agrupamentos que confirmaram a identidade taxonômica das linhagens usadas neste trabalho. A linhagem de $M$. album 201 agrupou com a seqüência de uma Inhagem da mesma espécie recuperada do banco de dados. Com relação à espécie $M$. flavoviride, foi 
observado que as linhagens 204 e 209 formaram um agrupamento com a linhagem de M. flavoviride recuperada do GenBank, embora a linhagem 204 tenha se mostrado filogeneticamente mais distante. As linhagens $E_{9}, B / V i$ e $C$ pertencentes à espécie $M$. anisopliae var. anisopliae mostraram-se filogeneticamente idênticas entre si e com relação à linhagem de $M$. anisopliae (AF516295). A linhagem 14, oriunda da Austrália, não se agrupou com as outras linhagens de $M$. anisopliae var. anisopliae, mostrando-se isolada no dendrograma e filogeneticamente distante das demais linhagens utilizadas nesta análise. Estes dados corroboram os resultados obtidos nas análises de PCR-RFLP, onde as diferenças de tamanho e composição de sequência desta linhagem são refletidas como perfis polimórficos (Figuras 4 e 5). Quanto à espécie Beauveria bassiana, as linhagens utilizadas neste estudo formaram um agrupamento coerente com a linhagem cuja sequência foi recuperada da base de dados (Figuras 8 e 9). 


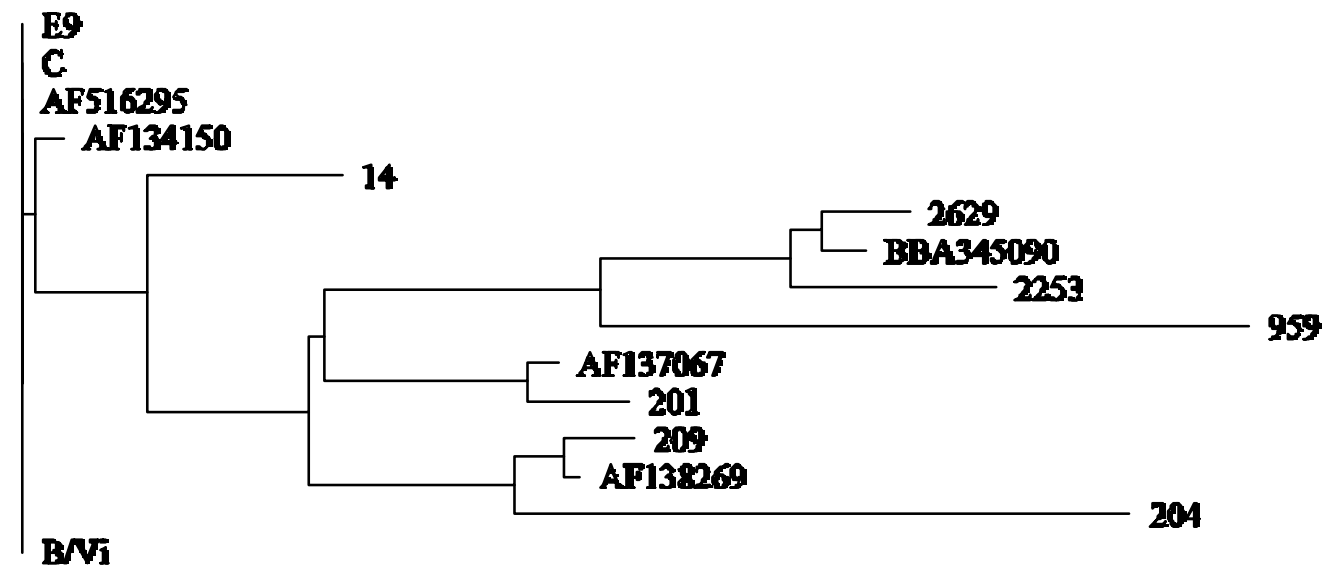

.10

Figura 8 - Dendrograma resultante do alinhamento das seqüências ITS1 - 5.8S - ITS2 DNAr de diferentes espécies de Metarhizium e Beauveria bassiana.

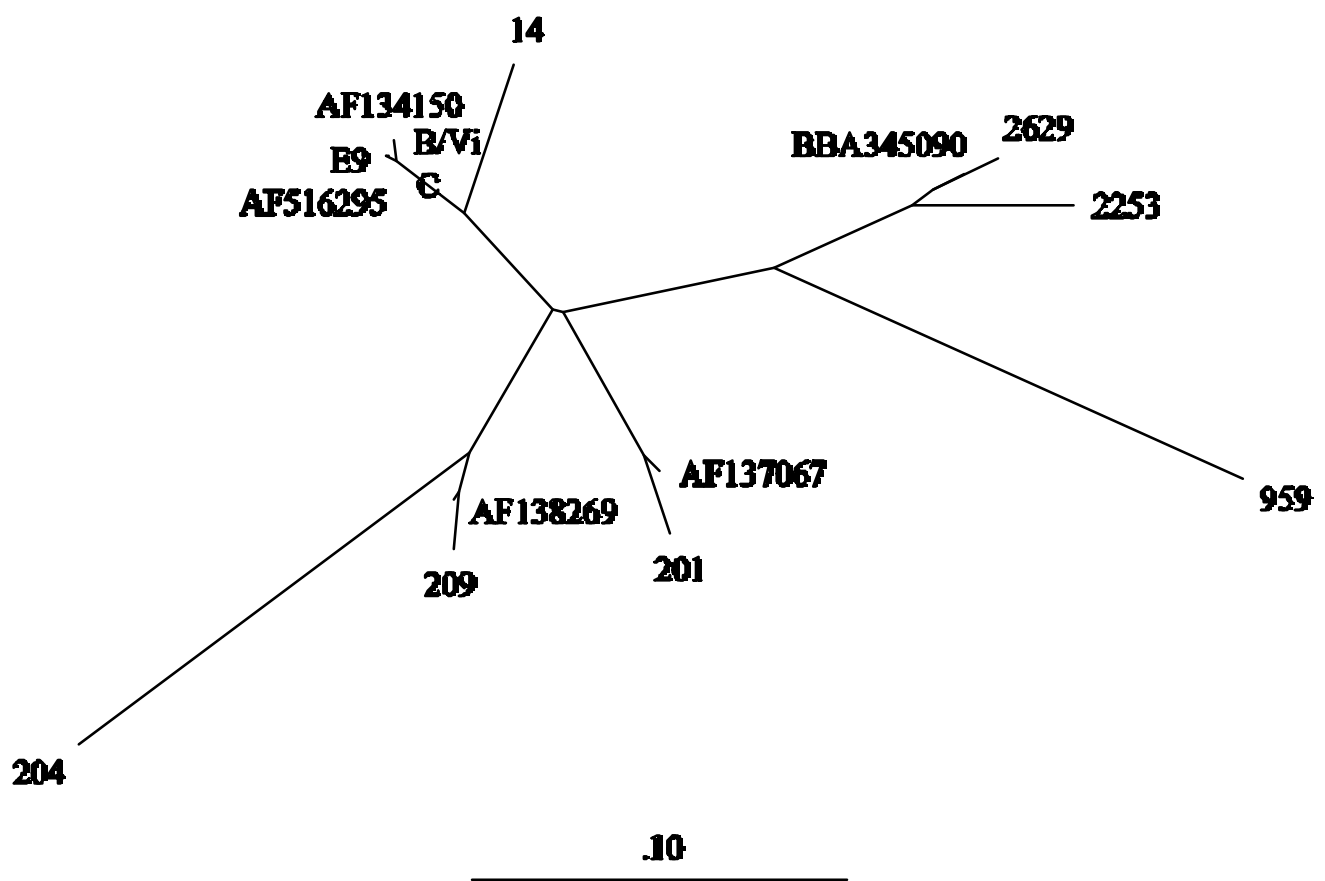

Figura 9 - Fenograma resultante do alinhamento das seqüências ITS1 - 5.8S - ITS2 DNAr de diferentes espécies de Metarhizium e Beauveria bassiana. 


\subsection{Desenho de primers específicos}

Os dados de alinhamento por meio do programa ClustalW revelaram diferenças claras entre as linhagens seqüenciadas e, portanto, decidiu-se desenhar apenas o primer forward e utilizar o primer ITS 4 como primer reverse. As análises de alinhamento mostraram que a região ITS da linhagem 14 de $M$. anisopliae é muito diferente das demais analisadas e, assim, optou-se em desenhar primers distintos para essas linhagens.

O primer forward específico para as linhagens $\mathrm{E}_{9}, \mathrm{~B} / \mathrm{Vi}$ e $\mathrm{C}$ de $M$. anisopliae foi denominado ITSMet (5' TCT GAA TTT TTT ATA AGT AT 3') com temperatura de anelamento $(\mathrm{Tm})$ de $46,5^{\circ} \mathrm{C}$; e para a linhagem 14 o primer foi denominado ITS14 (5' GAA ACC GGG ACT AGG CGC 3') com Tm de $66,8^{\circ} \mathrm{C}$. Foram realizados experimentos de gradiente de temperatura de anelamento para verificar qual a melhor condição para os diferentes pares de primers a serem analisados. A linhagem de M.a. var. anisopliae $\mathrm{E}_{9}$ foi utilizada nos testes com o par de primers ITSMet/ITS4 e a linhagem de M.a. var. anisopliae 14 nas amplificações com o par de primers ITS14/ITS4 (Figura 10). As amplificações resultaram num fragmento de aproximadamente $440 \mathrm{pb}$ com o par de primers ITSMet/ITS4 e 490 pb com ITS14/ITS4.

Os resultados desses experimentos mostraram que $46^{\circ} \mathrm{C}$ seria a temperatura de anelamento ideal para o par de primers desenhado para as linhagens $\mathrm{E}_{9}, \mathrm{~B} / \mathrm{Vi}$ e $\mathrm{C}$ e $61^{\circ} \mathrm{C}$ para $\mathrm{o}$ par de primers desenhado para a linhagem 14.

Após determinação das temperaturas ideais de amplificação, foram

realizados experimentos para determinação de condições específicas de amplificação para diferenciar a linhagem 14 das demais pertencentes à espécie de M. anisopliae var. anisopliae. Assim, as linhagens $E_{9}$ e 14 foram testadas com os primers ITSMet/ITS4 e ITS14/ITS4 nas temperaturas de anelamento de $46^{\circ} \mathrm{C}$ e $61^{\circ} \mathrm{C}$, respectivamente. O DNA extraído de inseto sadio foi também incluído nesses experimentos como controle negativo das amplificações. 

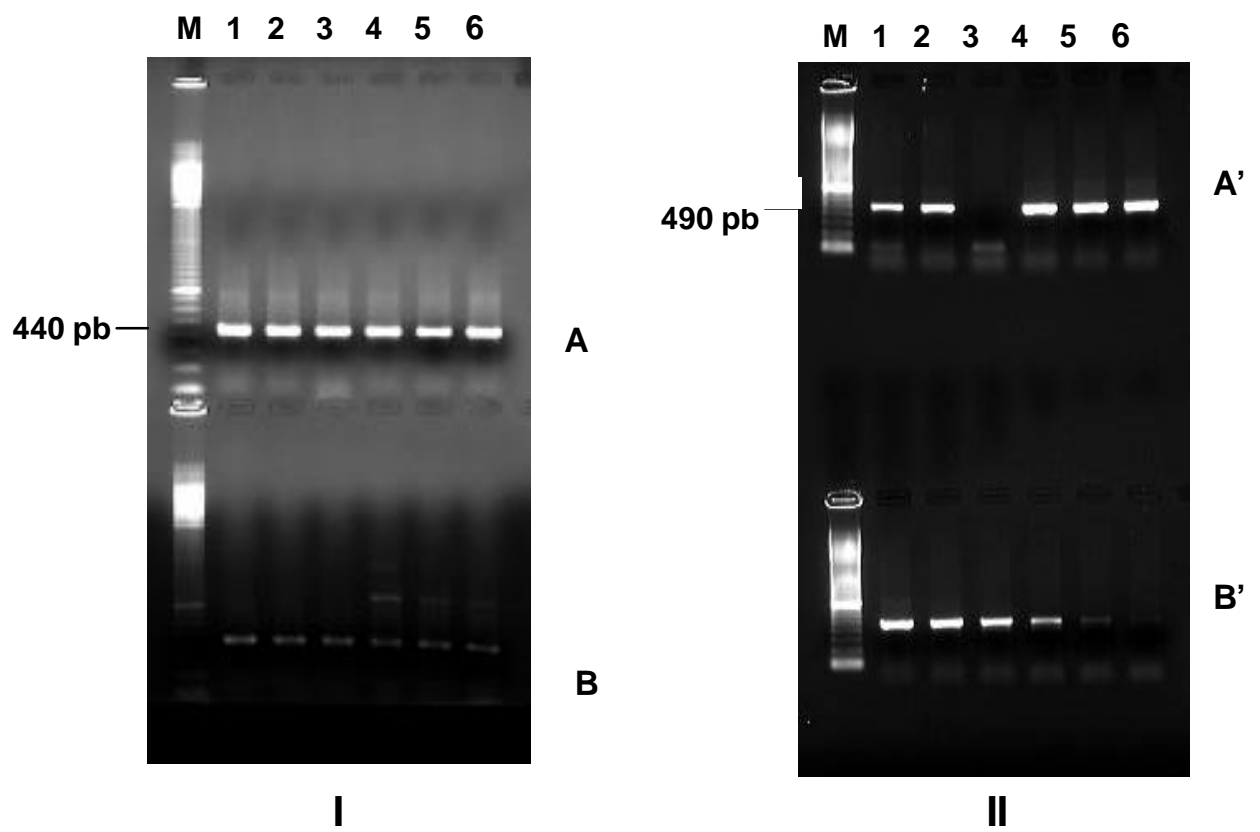

Figura 10 - (I) Gradiente de temperatura entre 40 e $55^{\circ} \mathrm{C}$ para teste de especificidade para $M$. anisopliae com o par de primers ITSMet/ITS4. (M) marcador de peso molecular de 100pb (Pharmacia). (A) (1) $40^{\circ} \mathrm{C}$; (2) $40,4^{\circ} \mathrm{C}$; (3) $41,2^{\circ} \mathrm{C}$; (4) $42,5^{\circ} \mathrm{C}$; (5) $44,2^{\circ} \mathrm{C}$; (6) $46,4^{\circ} \mathrm{C}$; (B) (1) $48,9^{\circ} \mathrm{C}$; (2) $51^{\circ} \mathrm{C}$; (3) $52,7^{\circ} \mathrm{C}$; (4) $53,8^{\circ} \mathrm{C}$; (5) $54,7^{\circ} \mathrm{C}$; (6) $55^{\circ} \mathrm{C}$. (II) Gradiente entre 50 e $62^{\circ} \mathrm{C}$ para teste de especificidade para a linhagem 14 com o par de primers ITS14/ITS4. (M) marcador de peso molecular de 100pb (Pharmacia). (A') (1) $50^{\circ} \mathrm{C}$; (2) $50,3^{\circ} \mathrm{C}$; (3) $50,9^{\circ} \mathrm{C}$; (4) $52^{\circ} \mathrm{C}$; (5) $53,4^{\circ} \mathrm{C}$; (6) $55,2^{\circ} \mathrm{C}$; (B') (1) $57,2^{\circ} \mathrm{C}$; (2) $58,9^{\circ}$; (3) $60,2^{\circ} \mathrm{C}$; (4) $61,1^{\circ} \mathrm{C}$; (5) $61,8^{\circ} \mathrm{C}$; (6) $62^{\circ} \mathrm{C}$.

A amplificação com o par de primers ITSMet/ITS4 a $46^{\circ} \mathrm{C}$, específico para as linhagens $\mathrm{E}_{9}, \mathrm{~B} / \mathrm{Vi}$ e $\mathrm{C}$, resultou na amplificação do fragmento de 440 pb com menor intensidade na linhagem 14. Quando a temperatura de anelamento foi aumentada para $47^{\circ} \mathrm{C}$, não ocorreu amplificação deste fragmento na linhagem 14, tornando-se a condição ideal para amplificação apenas das linhagens $\mathrm{E}_{9}$, B/Vi e C. Com relação ao par de primers ITS14/ITS4, específico para a linhagem de M.a. var. anisopliae 14, os experimentos foram 
efetuados com temperatura de anelamento de $60^{\circ} \mathrm{C}$ e $61^{\circ} \mathrm{C}$ e verificou-se que a $61^{\circ} \mathrm{C}$ não ocorre amplificação das linhagens de M.a. var. anisopliae $\mathrm{E}_{9}$, B/Vi e $\mathrm{C}$, tornando-se a condição ótima de especificidade para a amplificação da linhagem de M.a. var. anisopliae 14 (Figura 11).

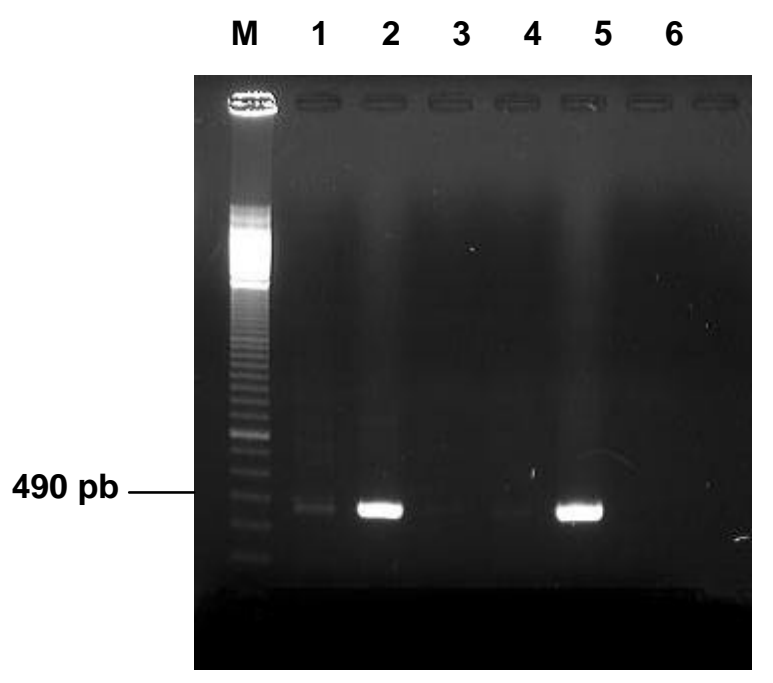

Figura 11 - Amplificação com o par de primers ITS14/ITS4 para teste de especificidade entre as linhagens $E_{9}$ e 14 de $M$. anisopliae e DNA do inseto sadio. (M) marcador de peso molecular de 100pb (Pharmacia). Temperatura anelamento de $60^{\circ} \mathrm{C}$ : (1) $\mathrm{E}_{9}$; (2) 14 ; (3) inseto; Temperatura de anelamento de $61^{\circ} \mathrm{C}$ : (4) $\mathrm{E}_{9}$; (5) 14 ; (6) inseto.

Foram desenhados também primers específicos para os fungos Metarhizium flavoviride, linhagem 209, e Beauveria bassiana, linhagens ARSEF 959,2253 e 2629. 


\subsection{Detecção de $M$. anisopliae var. anisopliae em insetos infectados}

Foram efetuadas extrações de DNA total de insetos infectados após 48h de exposição às linhagens de M. anisopliae var. anisopliae $\mathrm{E}_{9}, \mathrm{~B} / \mathrm{Vi}, \mathrm{C}$ e 14 . Os experimentos de amplificação com os primers ITSMet/ITS4 e ITS14/ITS4 foram realizados utilizando-se o DNA de culturas puras das respectivas linhagens do fungo como controle positivo e DNA de insetos sadios como controle negativo (Figura 12).

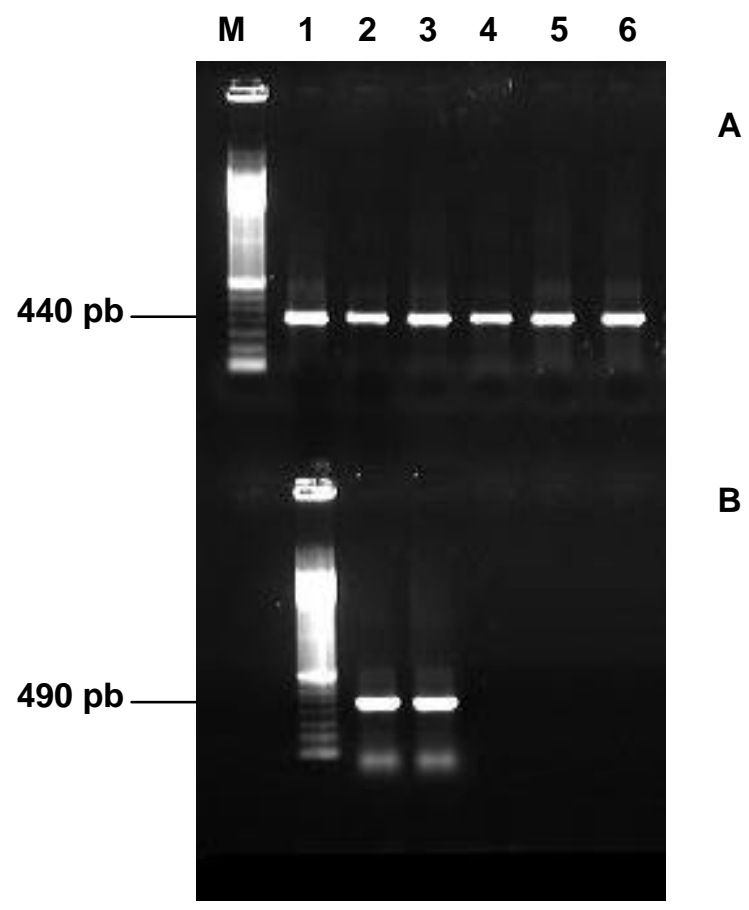

Figura 12 - Teste de amplificação com DNAs extraídos de insetos infectados utilizando-se os primers ITSMet/ITS4 (A) e (B) ITS14/ITS4.. (M) marcador de peso molecular de 100pb (Pharmacia) (A) (1) Eg; (2) $E_{9}+$ inseto; (3) B/Vi; (4) B/Vi+inseto; (5) C; (6) C+inseto; (B) (1) 14; (2) 14+inseto. 


\subsection{RFLP dos fragmentos específicos obtidos para confirmação da detecção de M.a. var. anisopliae nos insetos infectados}

A confirmação de que os fragmentos amplificados a partir do DNA extraído de insetos infectados correspondiam à região ITS de M.a. var. anisopliae foi efetuada por meio da utilização de enzimas de restrição, utilizando-se os DNAs extraídos de culturas puras do fungo como controle. Os produtos de amplificação foram digeridos com Afa I, Alu I, Dde I, Hae III, Sau 3A I e Taq I e os resultados obtidos estão ilustrados nas Figuras 13, 14, 15, e 16.

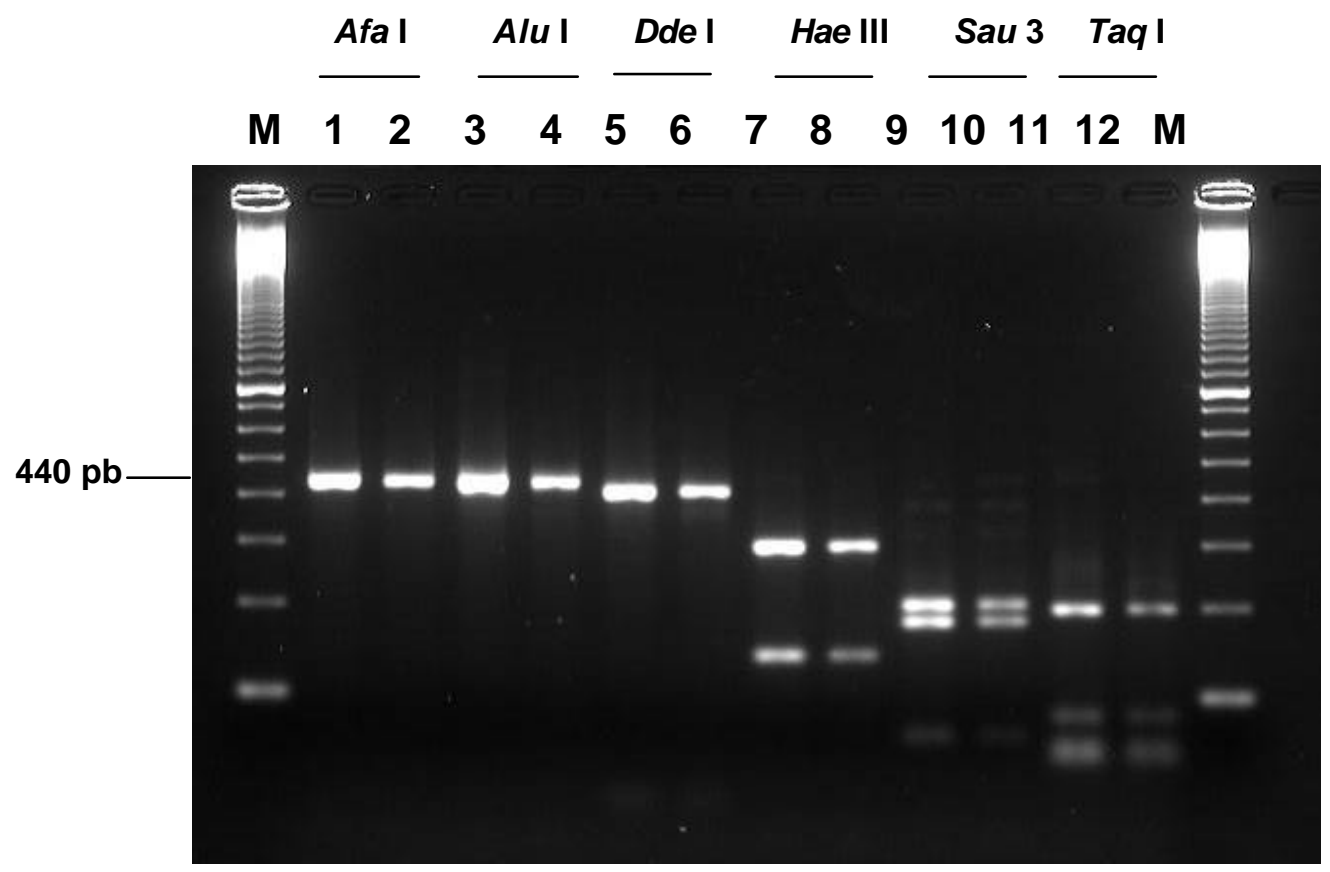

Figura 13 - Digestão dos produtos de amplificação gerados com o par de primers ITSMet/ITS4 com endonucleases de restrição. (M) marcador de peso molecular de 100pb (Pharmacia) (1) $\mathrm{E}_{9}$-Afa I; (2) $\mathrm{E}_{9}+$ inseto-Afa I; (3) $\mathrm{E}_{9}$-Alu I; (4) $\mathrm{E}_{9}+$ inseto-Alu I; (5) $\mathrm{E}_{9}$ Dde I; (6) $\mathrm{E}_{9}+$ inseto-Dde I; (7) $\mathrm{E}_{9}-\mathrm{Hae}$ III; (8) $\mathrm{E}_{9}+$ inseto-Hae III; (9) $\mathrm{E}_{9}-\mathrm{Sau} 3 \mathrm{~A} \mathrm{I}$; (10) $\mathrm{E}_{9}+$ inseto-Sau 3A I; (11) Eg-Taq I; (12) Eg+inseto-Taq I. 


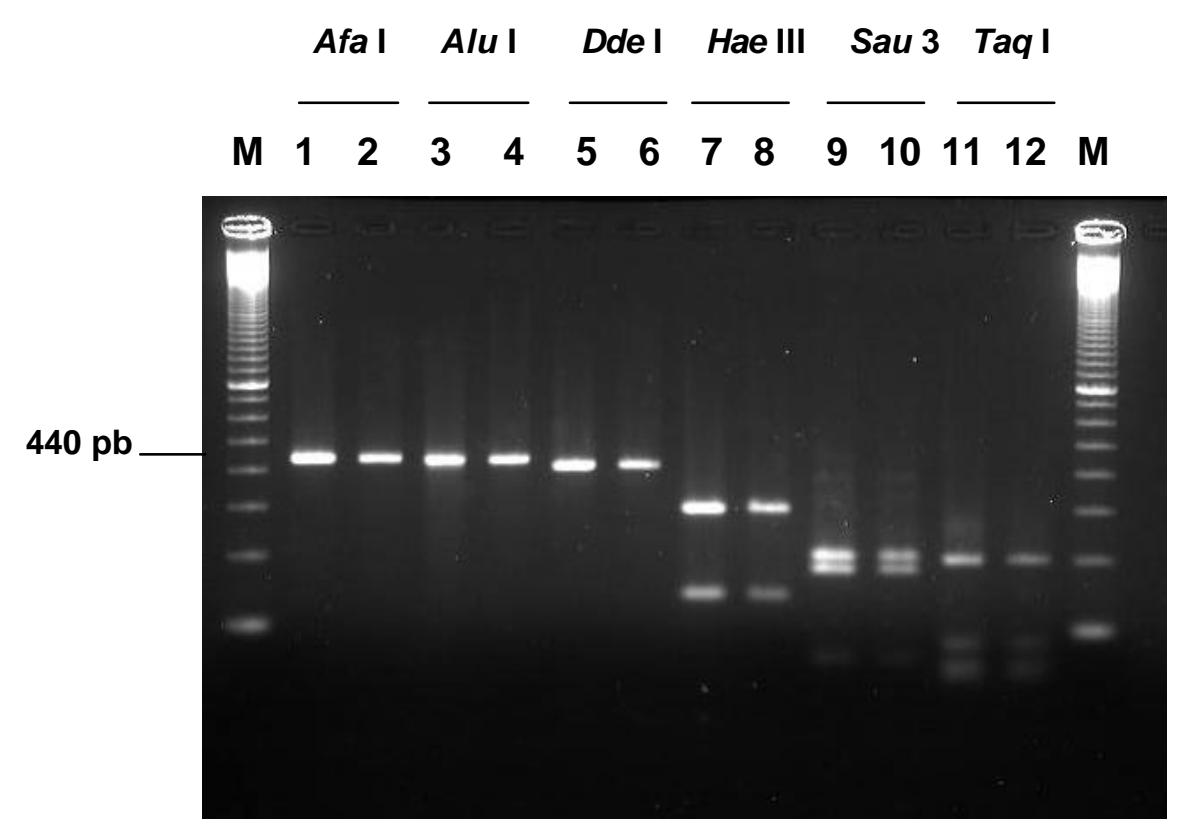

Figura 14 - Digestão dos produtos de amplificação gerados com os primers ITSMet/ITS4 com diferentes endonucleases de restrição. (M) marcador de peso molecular de $100 \mathrm{pb}$ (Pharmacia) (1) B/VI-Afa I; (2) B/Vi+inseto-Afa I; (3) B/Vi-Alu I; (4) B/Vi+inseto-Alu I; (5) B/Vi-Dde I; (6) B/Vi+inseto-Dde I; (7) B/Vi-Hae III; (8) B/Vi+inseto-Hae III; (9) B/Vi-Sau 3A I; (10) B/Vi+inseto-Sau 3A I; (11) B/Vi-Taq I; (12) B/Vi+inseto-Taq I. 


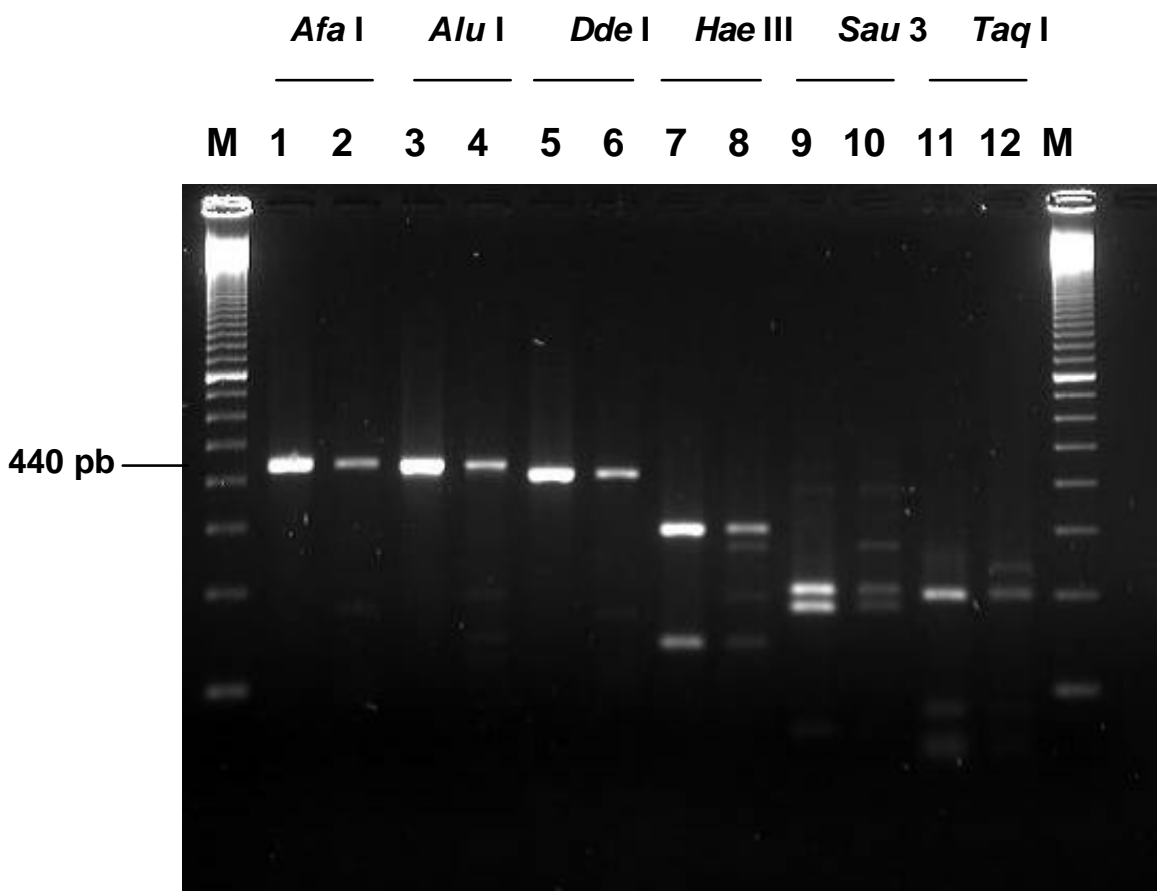

Figura 15 - Digestão dos produtos de amplificação gerados com o par de primers ITSMet/ITS4 com diferentes endonucleases de restrição. (M) marcador de peso molecular de $100 \mathrm{pb}$ (Pharmacia) (1) GAfa I; (2) C+inseto-Afa I; (3) C-Alu I; (4) C+inseto-Alu I; (5) GDde I; (6) C+inseto-Dde I; (7) GHae III; (8) C+inseto-Hae III; (9) GSau 3A I; (10) C+inseto-Sau 3A I; (11) C-Taq I; (12) C+inseto-Taq I. 


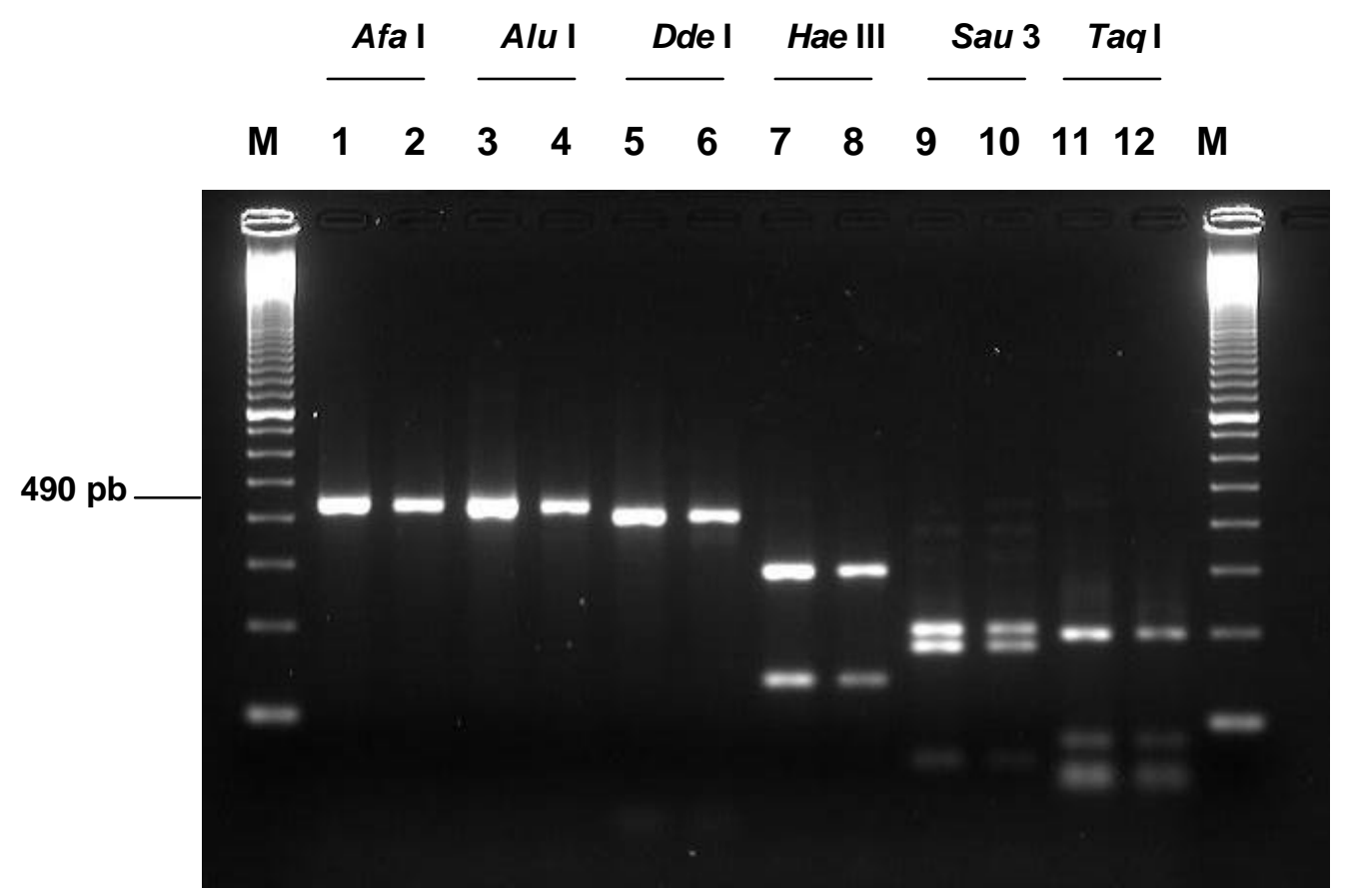

Figura 16 - Digestão dos produtos de amplificação gerados com o par de primers ITS14/ITS4 com diferentes endonucleases de restrição. (M) marcador de peso molecular de 100pb (Pharmacia) (1) 14-Afa I; (2) 14+inseto-Afa I; (3) 14-Alu I; (4) 14+inseto-Alu I; (5) 14-Dde I; (6) 14+inseto-Dde I; (7) 14-Hae III; (8) 14+inseto-Hae III; (9) 14-Sau 3A I; (10) 14+inseto-Sau 3A I; (11) 14-Taq I; (12) 14+inseto-Taq I. 


\section{DISCUSSÃO}

Estudos relacionados à utilização de micoinseticidas biológicos têm sido realizados representando uma inovação alternativa para o controle de pragas. De forma paralela há uma grande preocupação em relação aos efeitos positivos e negativos inerentes a toda nova forma de controle. O monitoramento de todas as fases de uma implementação de projetos de manejo de pragas envolvendo microrganismos é uma necessidade, pois a produção e aplicação de tais organismos devem ser acompanhadas de procedimentos de padronização rigorosa e mecanismos de avaliação de dispersão e instalação de epizootias no meio ambiente, através de metodologia específica e com maior segurança possível.

Os poucos micoinseticidas prontos para utilização em escala comercial requerem ferramentas sensíveis e específicas para identificação tanto no estágio de produção como em situação de campo. Entre os exemplos de fungos disponíveis no mercado ou aqueles que estão em desenvolvimento em alguns países encontram-se os gêneros Beauveria, Cordyceps, Entomophthora, Metarhizium, Nomureae, Paecilomyces e Verticillium (Alves, 1998).

As vantagens em se utilizar o fungo Metarhizium no controle microbiano de pragas são a simplicidade de produção em larga escala das suas unidades infectivas, os conídios, a facilidade de aplicação destes em condições de campo, e atualmente o baixo custo decorrido de sua utilização, além do reduzido impacto ambiental.

A necessidade de se desenvolver uma metodologia bastante precisa de diagnóstico da doença causada pelo fungo, num período relativamente curto, 
representa grande auxílio no monitoramento da introdução, dispersão e controle da ação entomopatogênica do fungo utilizado tanto para os insetos pragas como para os insetos não alvo, e, ainda, a segurança certificada da ação efetiva e específica do microrganismo em nível de gênero, e em muitos casos até em nível de espécie.

O objetivo deste trabalho foi construir primers específicos que funcionassem com precisão como marcadores moleculares para a detecção e identificação de Metarhizium anisopliae, durante o processo infeccioso em larvas de broca da cana-de-açúcar Diatraea saccharalis utilizadas como inseto hospedeiro.

O período de 48 horas após o contato entre o patógeno e o hospedeiro, representou um espaço curto de tempo para a recuperação e identificação segura do entomopatógeno dentro do hospedeiro, dado que, por meio de metodologias microbiológicas e bioquímicas clássicas, um tempo muito maior seria necessário para a realização de testes de confirmação da efetiva infecção.

Historicamente, a identificação de fungos entomopatogênicos vinha sendo realizada somente baseada na conidiogênese celular, morfologia dos esporos, características bioquímicas, e propriedades imunológicas. Para Beauveria bassiana, diversas técnicas de genética molecular foram desenvolvidas (Kosir et al., 1991; Pfeifer \& Khachatourians, 1993) incluindo a construção de uma série de probes de DNA genômico que exibem especificidade para $B$. bassiana, inclusive para discriminação entre isolados (Hegedus \& Khachatourians, 1993a).

A identificação individual de linhagens através da utilização dos fingerprintings genômicos apresenta uma série de aplicações práticas para os programas de melhoramento genético de fungos entomopatogênicos. Ela torna possível o acompanhamento individual de linhagens utilizadas em ensaios de competição no campo e a distinção entre as linhagens ensaiadas e as autóctones. Ensaios de persistência ambiental também poderão ser conduzidos de maneira mais precisa e segura (Braga, 1997). 
A amplificação de ácidos nucleicos pelo processo de PCR ("Polymerase Chain Reaction") revolucionou muitos procedimentos na biologia molecular, inclusive as metodologias relacionadas com identificação e tipagem de microrganismos. O protocolo de extração de DNA genômico total utilizado neste estudo produziu uma quantidade reduzida de DNA das larvas infectadas pelo fungo em comparação com as extrações efetuadas com material de culturas puras de Metarhizium, porém suficiente para os experimentos de amplificação. Dados de literatura mostram que a amplificação de DNA de amostras ambientais é freqüentemente difícil devido à presença de compostos inibitórios que interferem nos experimentos de PCR (Hegedus and Khachatourians, 1996b). Ainda, amostras de plantas (Do \& Adams, 1991) e fungos (Pfeifer \& Khachatourians, 1993) podem conter certos polissacarídeos que podem causar problemas na amplificação. No caso do isolamento de DNA de insetos, a cutícula pode apresentar um número significativo de compostos, considerados fortes inibidores da PCR (Hackman, 1974). Neste trabalho, o protocolo utilizado (Garber \& Yoder, 1983) permitiu a obtenção de DNA de larvas infectadas com pureza suficiente para a amplificação direta dos produtos específicos, sendo que os produtos obtidos apresentaram concentração de DNA muito semelhante à obtidas com material de culturas puras.

Ferramentas moleculares, incluindo a análise de polimorfismos de fragmentos de restrição (RFLP) do DNA mitocondrial e nuclear, amplificação de fragmentos específicos com o uso de oligonucleotídeos também desenhados específicamente, para uso em PCR da região espaçadora intergênica (ITS) e das subunidades do DNAr, têm sido utilizadas para analisar variações inter e infra-específicas em várias espécies de fungos (Bruns et al., 1991).

A amplificação de genes ribossomais e regiões espaçadoras ITS e IGS tem sido amplamente utilizada em estudos de taxonomia (Driver et al., 2000), de filogenia (Rakotonirainy et al., 1994), de diversidade genética (Anderson et al., 2001; Letake et al. 2002) e na identificação e diferenciação de espécies (Fouly et al., 1997). 
As linhagens de M. anisopliae var. anisopliae, M. album e M. flavoviride foram examinadas com relação ao gene ribossomal $18 \mathrm{~S}$ e as análises de polimorfismos deste gene revelaram diferenças que puderam separar as espécies de Metarhizium, dependendo da enzima de restrição utilizada, entretanto, este marcador tem sido indicado para diferenciação em nível de gênero. Por outro lado, as regiões ITS e IGS são menos conservadas e, portanto, mais adequadas para estudos em nível de espécie e infra-específicos. No presente estudo, os produtos amplificados, correspondentes à região espaçadora ITS1 - 5.8S - ITS2, mostraram variação no tamanho entre as espécies de Metarhizium analisadas. A variação no tamanho de produtos de amplificação tem sido apontada como um bom marcador molecular para muitas espécies de fungos (Pechia et al., 1998; Fouly et al., 1997; Jiang \& Hiruki, 1996). No presente trabalho, a amplificação da região espaçadora ITS1 - 5.8S - ITS2 resultou em fragmentos de tamanhos diferentes para as três espécies analisadas, sendo que dentro da espécie M.a. var. anisopliae a linhagem 14, oriunda da Austrália, apresentou fragmento maior que as linhagens da mesma espécie oriundas do Brasil.

Em estudos de variabilidade genética de fungos tem sido comum o uso de primers correspondentes à região ITS para a identificação de espécies (Anderson et al., 1998). O alto polimorfismo da região espaçadora obtido com as diferentes endonucleases de restrição (PCR-RFLP) permitiu concluir que esta região pode ser tranqüilamente utilizada como marcador molecular para diferenciação das espécies $M$. anisopliae var. anisopliae, $M$. album e $M$. flavoviride. O dendrograma construído a partir desses dados mostrou claramente que a linhagem 14 de M.a. var. anisopliae é realmente diferente das demais da mesma espécie e que $M$. album e M. flavoviride constituem grupos bem distintos (Figura 6).

A variabilidade detectada nas seqüências ITS tem sido considerada como uma ferramenta muito útil na discriminação de diferentes espécies de fungos (Neuveglise et al., 1994; Fouly et al., 1997; Jensen \& Eilenberg, 2001; 
Anderson et al., 2001; Thomsen \& Jensen, 2002). Nossos dados de PCR-RFLP mostraram que a variação no tamanho e sítios de restrição na região ITS1 5.8S - ITS2 poderia ser utilizada para a construção de primers específicos para essas linhagens. Além das linhagens de Metarhizium utilizadas neste estudo, linhagens de Beauveria bassiana também foram incluídas nos experimentos de sequenciamento da região espaçadora, uma vez que este fungo também é amplamente utilizado no controle microbiano de pragas, e primers específicos para a detecção e identificação deste microrganismo também seria interessante. O seqüenciamento dessa região permitiu a comparação com seqüências de outras linhagens de Metarhizium depositadas no banco de dados GenBank e o alinhamento e análise filogenética confirmaram a identidade taxonômica dos isolados em estudo. Esses resultados corroboram com Rakotonirainy et al. (1994), que utilizando a técnica de seqüenciamento do gene 28S DNAr e análises filogenéticas, puderam separar $M$. flavoviride de $M$. anisopliae. Neste mesmo estudo foi verificado que linhagens da espécie $M$. anisopliae oriundas da Nova Zelândia são geneticamente muito distantes das linhagens típicas da mesma espécie. Os resultados obtidos neste estudo com a linhagem 14, oriunda da Austrália, sugerem que a espécie $M$. anisopliae pode conter um grupo de isolados que tenham evoluído geneticamente de forma diferente, entretanto, um número maior de isolados de áreas geográficas próximas devem ser investigados para confirmação de tal hipótese.

Os dados de seqüenciamento da região ITS1 - 5.8S - ITS2 obtidos neste estudo permitiram o desenho do primer ITSMet, específico para as linhagens de $M$. anisopliae oriundas do Brasil e ITSMet14 para a linhagem 14 oriunda da Austrália. A estratégia de utilizar o primer ITS4 como primer reverse mostrou-se adequada, pois os fragmentos específicos obtidos corresponderam aos fragmentos esperados.

Primers específicos têm sido desenvolvidos para a detecção e identificação de alguns fungos entomopatogênicos como Beauveria bassiana (Hegedus \& Khachatourians, 1996b), Gliocladium catenulatum (Paavanen- 
Huhtala et al., 2000) e Metarhizium anisopliae (Leal et al, 1997). O conjunto de primers ITSMet/ITS4, correspondente à região ITS de M.a. var. anisopliae, mostrou-se altamente específico para a diferenciação das espécies de $M$. anisopliae, M. album e M. flavoviride. Nos experimentos preliminares de amplificação com DNA obtido de culturas puras verificou-se o aparecimento de uma banda de amplificação de baixa intensidade para a linhagem 14, considerada muito distinta das linhagens de M.a. var. anisopliae oriundas do Brasil. Entretanto, este fato não ocorreu quando o DNA testado era proveniente de larvas infectadas pelo fungo. Embora relatos de literatura mostrem que amostras de DNA de insetos podem conter inibidores de amplificação por PCR (Hackman, 1974), a quantidade de DNA dos produtos obtidos nas amplificações utilizando-se os primers específicos foi muito similar à obtida com culturas puras. Em adição, primers específicos para $M$. album, $M$. flavoviride e Beauveria bassiana também puderam ser desenvolvidos.

Sistemas de detecção baseados no DNA para o estudo de patologia de insetos apresentam uma grande vantagem uma vez que o agente fúngico pode ser detectado dentro de insetos infectados ou tecidos, antes da sua morte ou princípio de mumificação e sem o uso de métodos não específicos como a microscopia (Hegedus \& Khachatourians, 1996b). Hegedus \& Khachatourians (1996b), trabalhando com Beauveria bassiana, verificaram que o fungo pode ser detectado depois de 5 a 7 dias pós-inoculação em Melanoplus sanguinipes (gafanhoto migratório), sugerindo que este nível de sensibilidade seria suficiente para detectar o fungo dentro dos insetos infectados antes da emergência das estruturas do patógeno para o exterior dos cadáveres.

$\mathrm{Em}$ nossos experimentos a presença do fungo $M$. anisopliae var. anisopliae dentro do hospedeiro Diatraea saccharalis pode ser detectada 48 horas após o contato patógeno-hospedeiro, por meio da utilização de amplificação por PCR com primers específicos; ou seja, o presente estudo desenvolveu um sistema simples, rápido, específico e seguro para detecção 
deste fungo dentro do hospedeiro sem a necessidade da utilização de técnicas como hibridização e seqüenciamento. 


\section{CONCLUSÕES}

1 o protocolo de extração de DNA utilizado permitiu a obtenção de DNA com de boa qualidade, sem degradação e possivelmente isento de inibidores, uma vez que não houve diferença na quantidade de DNA obtida nas amplificações com DNA de culturas puras e DNA de larvas infectadas;

2 a metodologia de polimorfismo da região ITS1 - 5.8S - ITS2 (PCRRFLP) mostrou-se altamente eficiente para diferenciação das espécies de Metarhizium anisopliae var. anisopliae, M. album e M. flavoviride;

3 o alinhamento e análises filogenéticas permitiram o desenvolvimento de primers específicos para as diferentes espécies de Metarhizium;

4 o conjunto de primers ITSMet/ITS4 mostrou-se específico para as linhagens de M.a. var. anisopliae $\mathrm{E}_{9}$, B/Vi e C;

5 o conjunto de primers ITSMet14/ITS4 foi desenvolvido especificamente para a detecção da linhagem 14 de M.a. var. anisopliae oriunda da Austrália, a qual mostrou-se distinta das outras linhagens da mesma espécie;

6 a técnica de restrição com endonucleases dos produtos de amplificação obtidos de DNA de larvas infectadas utilizando-se os primers específicos desenhados mostrou-se adequada para confirmação da identificação do fungo dentro do inseto; 
7 a utilização dos primers específicos ITSMet e ITSMet14 na detecção e identificação de $M$. anisopliae var. anisopliae permitirá avaliar a padronização de produção deste entomopatógeno em nível de laboratório ou escala comercial, e, a eficiência, especificidade ao hospedeiro, persistência e distribuição temporal-espacial de linhagens do fungo no campo. Esta técnica poderá ser também de muita utilidade em monitoramento de linhagens de fungos liberados em campo como agentes microbianos de controle em determinados ecossistemas. 
ANEXO: Alinhamento de sequências 
ANEXO - Alinhamento das sequências de nucleotídeos da região ITS1 - 5.8S ITS2 das linhagens de M.a. var. anisopliae $\mathrm{E}_{9}, \mathrm{~B} / \mathrm{Vi}, \mathrm{C}$ e14; M. album 201; M. flavoviride 204 e 209; Beauveria bassiana 959, 2253 e 2629; e outras seqüências ITS disponíveis no banco de dados GenBank database: M.a. var. anisopliae (AF516295 e AF134150), M. album (AF137067), M. flavoviride (AF138269) e Beauveria bassiana (BBA345090). Os primers específicos desenvolvidos ITSMet and ITSMet14 estão assinalados em caixas coloridas.

AF516295
AF 134150
E9
C
B/Vi
14
2629
BBA345090
2253
209
AF 138269
204
AF 137067
201
959

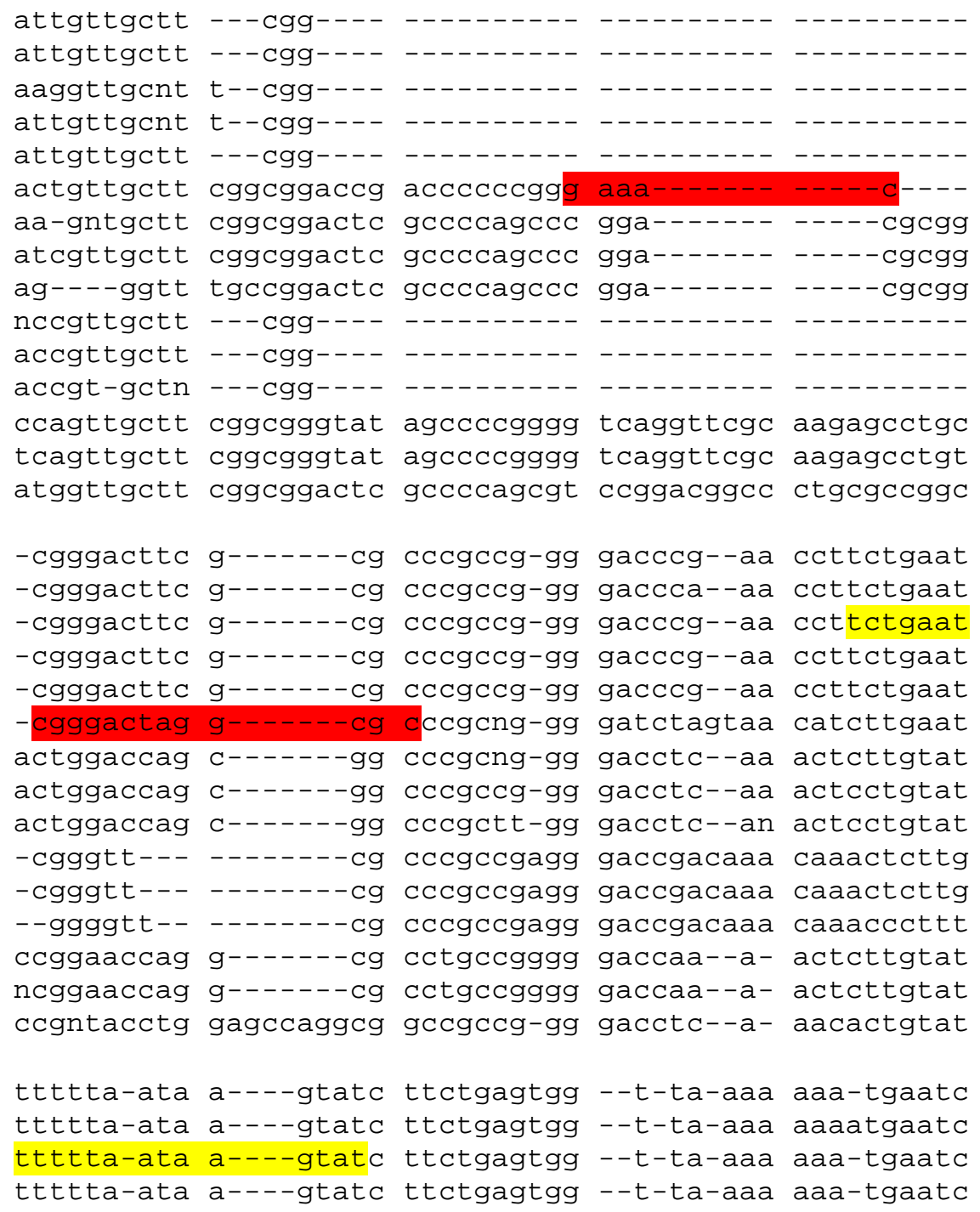




\begin{tabular}{|c|c|c|c|c|}
\hline & ---- gtatc & & $--t-t a-a a a$ & \\
\hline ttctatata & tatggcatc & ttctgagtgg & $--t-g g g a a a$ & aaatga \\
\hline ccagc-atc & tct-gaata & cgccgcaagg & $--c-a a-a a c$ & aaa-tgaatc \\
\hline ccagc-atc & tct-gaata & cgccgcaagg & $--c-a a a a a c$ & aaa-tgaatc \\
\hline cagcatctt & t---gaata & cgccgcaagg & $--c-a a a a c$ & aaa-tgaatc \\
\hline atttctatc & t-atagcatg & t-ctgagtgg & aat-cataca & caatgaatc \\
\hline tatc & t-atagcatg & t-ctgagtgg & aat-cataca & gaatc \\
\hline tettctatc & t-atagcatg & t-ctgagggg & aat-cataca & caatg \\
\hline ctgt-acg & ataaggaa & t-ctgagtgg & tttata & tc \\
\hline tctgt-acg & ataaggaa & t-ctgagtgg & tttatagaag & atc \\
\hline tcatcagtc & tctctga & $\operatorname{cgccgc}$ & $\mathrm{c}------\mathrm{a} a \mathrm{c}$ & tc \\
\hline & caac & ct & ggcat & \\
\hline & $\mathrm{Ca}$ & tcttggt & $=9$ & \\
\hline aactteca & caacgg & tcttggtt & gcatc & \\
\hline aactttca & caacgga & tcttggtt & ggcatc & aacgcag \\
\hline & C & tcttggt & ratg & cag \\
\hline ttca & caacg & tcttggt & ggcatc & cag \\
\hline tca & $\mathrm{C}$ & tctto & $=9$ & ag \\
\hline tca & acaacgo & tcttg & ggcat & zag \\
\hline & & & & \\
\hline ttca & acaac & tct & =g & ag \\
\hline tca & $\mathrm{Ca}$ & tct & & \\
\hline tta & $\mathrm{aco}$ & tct & $=9$ & $\mathrm{ac}$ \\
\hline & C & tct & $=9$ & \\
\hline $\mathrm{ca}$ & $\mathrm{C}$ & tct & $\operatorname{tg}$ & ag \\
\hline & $\mathrm{aca}$ & tct & gcat & ag \\
\hline & & & & \\
\hline & & gaz & a & $\operatorname{atc}$ \\
\hline & & & a & \\
\hline gcga & taa & gaa & atto & \\
\hline cga & tac & gaa & attc & tc \\
\hline & & ra & att & \\
\hline & & & $a$ & \\
\hline & tad & gaa & atc & \\
\hline & tac & ga & $a$ & tc \\
\hline & & $y a$ & $a$ & \\
\hline & & a & $a$ & atc \\
\hline & & gaa & & tc \\
\hline & & caga & attcag & atc \\
\hline & & & a & atc \\
\hline & & ga & attt & $\operatorname{aatc}$ \\
\hline & & & & \\
\hline & & & & \\
\hline & cat & gtc & $\operatorname{tggcgg}$ & $\mathrm{cga}$ \\
\hline & cat & gtc & $\operatorname{tgg}$ & ga \\
\hline $\mathrm{Ca}$ & cat & gtc & $\operatorname{tggcgg}$ & cga \\
\hline tttgaa & cattg & gtc & tggcgg & \\
\hline tttgaa & cattgc & $\operatorname{gcca}$ & $\operatorname{tggcgg}$ & c cga \\
\hline & & & tggcgggcat & \\
\hline tttgaa & cattgo & gcca & tggcgggcat & tgt \\
\hline tttgaa & & & & \\
\hline
\end{tabular}




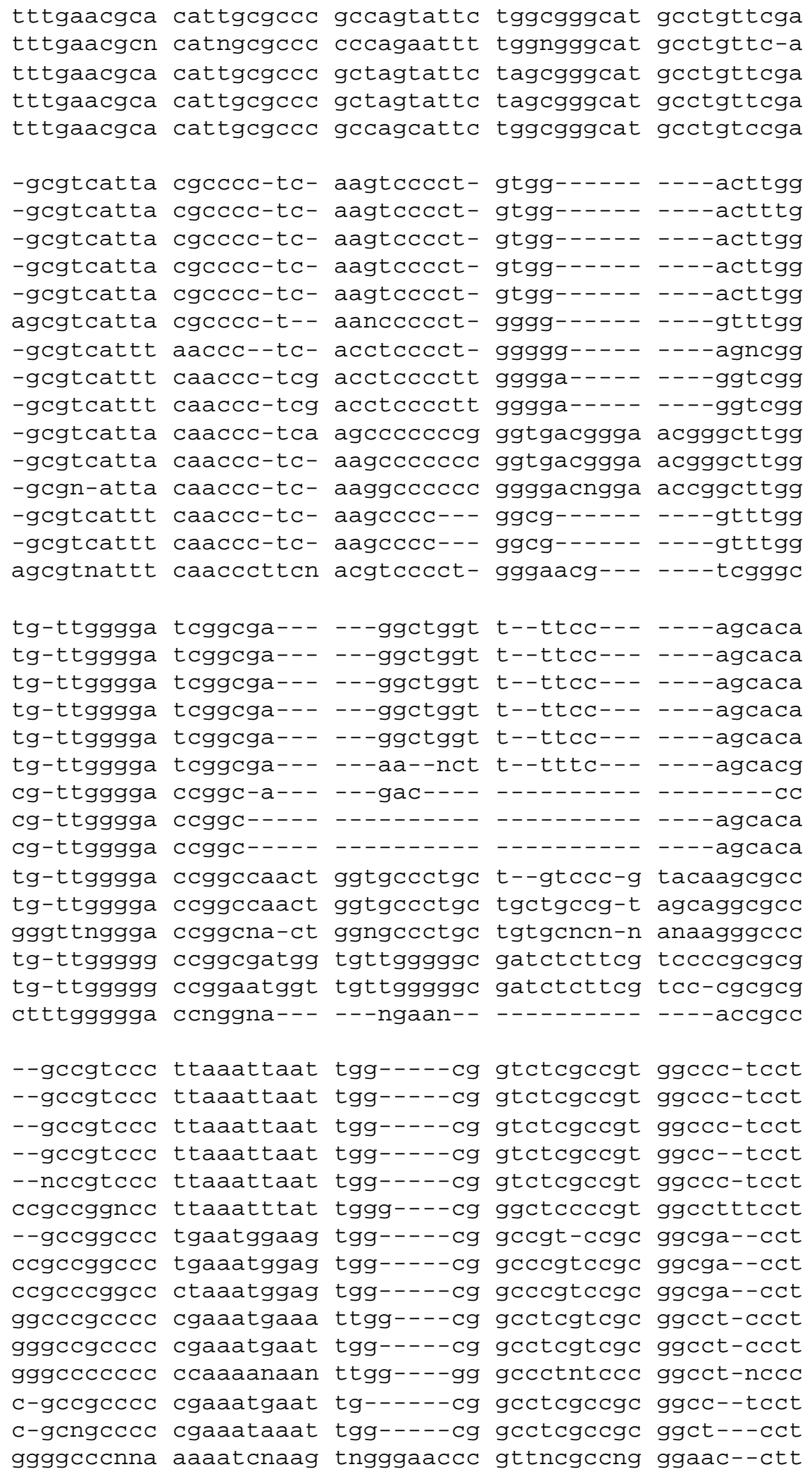




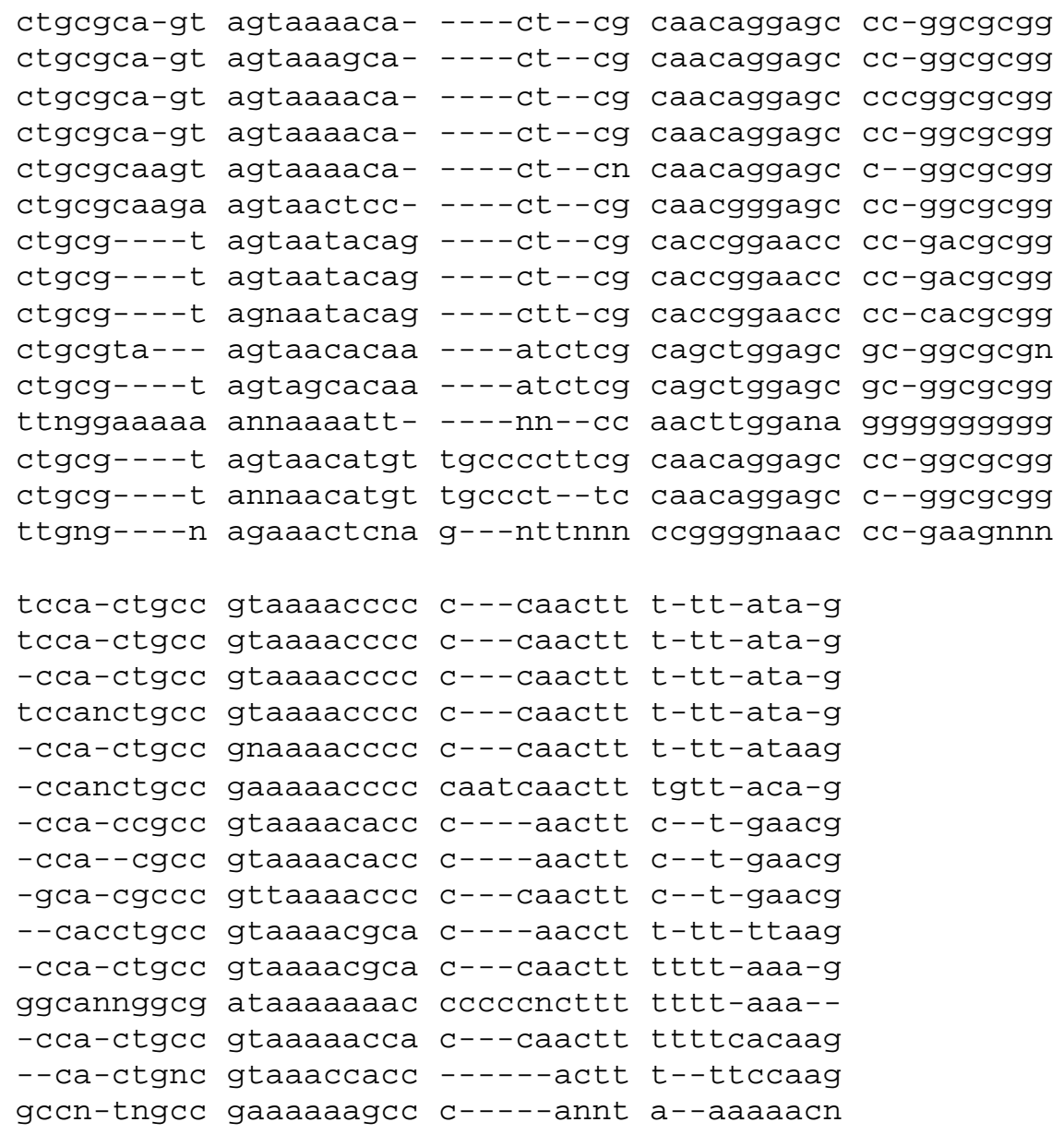




\section{REFERÊNCIAS BIBLIOGRÁFICAS}

AGUIAR, N.T.O. Variabilidade em linhagens de Metarhizium anisopliae var. anisopliae (Metsch.) SOROKIN quanto a germinação de conídios, conteúdo proteico, atividade enzimática. Campinas, 1990. 163p. Tese (Doutorado) Universidade Estadual de Campinas.

AL-AIDROOS, K.; ROBERTS, D.W. Mutantes of Metarhizium anisopliae with increased virulence toward mosquito larvae. Canadian Journal of Genetic Cytology, v.22, p.211-212, 1978.

AL-AIDROOS, K. Demonstration of a parasexual cycle in the entomopathogenic fungus Metarhizium anisopliae. Canadian Journal of Genetic Cytology, v.22, p.309-314, 1980.

ALVES, S.B. Agentes entomopatogênicos no controle microbiano. In: ALVES, S.B. (Coord.). Controle microbiano de insetos. São Paulo: Manole, 1986. p.73-126.

ALVES, S.B. (Ed.). Controle microbiano de insetos. Piracicaba: FEALQ, 1998. 1163p.

ALVES, S.B.; VIEIRA, S.A.; MACEDO, D.; LOPES, R.B. Diversidade genética de isolados de Metarhizium anisopliae detectada por PCR-RAPD e patogenicidade à Diatraea saccharalis. In: SIMPÓSIO DE CONTROLE BIOLÓGICO, 7., Poços de Caldas, 2001. Resumos. Poços de Caldas: SBE, 2001. p.175. 
ANDERSON, I.; CHAMBERS, S.M.; CAIRNEY, J.W.G. Molecular determination of genetic variation in Pisolithus isolates from a defined region in New South Wales, Australia. New Phytology, v.138, p.151-162, 1998.

ANDERSON, I.C.; CHAMBERS, S.M.; CAIRNEY, W.G.J. ITS-RFLP and ITS sequence diversity in Pisolithus from central and eastern Australian sclerophyll forests. Mycological Research, v.11, p.1304-1312, 2001.

ANDERSON, J.B.; STASOVSKI, E. Molecular phylogeny of northern hemisphere species of Armillaria. Mycologia, v.84, n.4, p.505-516, 1992.

BAGAGLI, E. Parameiose em Metarhizium anisopliae (Metsch.) SOROKIN. Piracicaba, 1987. 123p. Dissertação (M.S.) - Escola Superior de Agricultura "Luiz de Queiroz", Universidade de São Paulo.

BALFOUR-BROWNE, F.L. The green muscardine diseases of insects with special reference to an epidemic in a sworm of Locusts in ERITREA. Proceedings of Royal Entomological Society of London, v.12, p.12981301, 1960.

BERBEE, M.L.; TAYLOR, J.W. From 18S ribosomal sequence data to evolution of morphology among the fungi. Canadian Journal of Botany, v.73, p.S677-S683, 1995.

BINDSLEV, L.; OLIVER, R.P.; JOHANSEN, B. In situ PCR for detection and identification of fungal species. Mycological Research, v.106, p.277-279, 2002.

BIDOCHKA, M.J.; McDONALD, M.A.; St. LEGER, R.J.; ROBERTS, D.W. Differentiation of species and strains of entomopathogenic fungi by Random Amplification of Polymorphic DNA (RAPD). Current Genetics, v.25, p.107113, 1994. 
BRAGA, G.U.L. Caracterização fisiológica e molecular de linhagens de Metarhizium anosopliae. Campinas, 1997. 128p. Tese (Doutorado) Universidade Estadual de Campinas.

BRAGA, G.U.L.; VENKOVSKY, R.; MESSIAS, C.L. Estimates of genetic parameters related to chitinase production by Metarhizium anisopliae. Genetics and Molecular Biology, v.21, p.171-177, 1998.

BRUNS, T.D.; WHITE, T.J.; TAYLOR, J.W. Fungal molecular systematics. Annual Review of Ecology Systematic, v.22, p.525-564, 1991.

CHEUNG, P.Y.K.; GRULA, E.A. In vivo events associated with entomopathology of Beauveria bassiana for the corn earworm (Heliothis zea). Journal of Invertebrate Pathology, v.39, p.303-313, 1982.

COBB, B.D.; CLARKSON, J.M. Detection of molecular variation in the insect pathogenic fungus Metarhizium using RAPD-PCR. FEMS Microbiology Letters, v.12, p.319-324, 1993.

COSTA, A.S. Taxonomia polifásica de Neurospora produtoras de aroma. Campinas, 1999. 109p. Tese (Doutorado) - Universidade Estadual de Campinas.

DO, N.; ADAMS, R.P. A simple technique for removing plant polysaccharide contaminants from DNA. BioTechniques, v.10, p.162-166, 1991.

DRIVER F.; MILNER R.J.; TRUEMAN, J.W.H. A taxonomic revision of Metarhizium based on a phylogenetic analysis of rDNA sequence data. Mycological Research, v.2, p.134-150, 2000. 
ESTEVE-ZARZOSO, B.; BELLOCH, C.; URUBURU, F.; QUEROL, A. Identification of yeasts by RFLP analysis of 5.8S rRNA gene and the two ribossomal internal transcribed spacers. International Journal of Systematic Bacteriology, v.49, p.329-337, 1999.

FARGUES, J.; DURIEZ, T.; ANDRIEV, S.; POPEYE, R.; ROBERT, P. Étude immunologique comparée de souches de Metarhizium anisopliae (DELACR.) sien champignom hyphomycéte entomopathogéne. Comptes Rendus Hebdomadaires de Séances Del' Academie des Sciences, v.281, Sér.D, p.1781-1784, 1975.

FARGUES, J.; ROBERT, P.H. Persistance des conidiospores des hyphomycetes entomopathogenes $B$. bassiana, $M$. anisopliae et Paecilomyces fumosoroeus dans le sol, en conditions controle'es. Agronomie, v.5, n.1, p.73-80, 1985.

FEGAN, M.; MANNERS, J.M.; MACLEAN, D.J.; IRWIN, J.A.G.; SAMUELS, K. D.Z.; HOLDOM, D.G.; LI, D.P. Random amplified polymorphic DNA markers reveal a high-degree of genetic diversity in the entomopathogenic fungu Metarhizium anisopliae var. anisopliae. Journal of General Microbiology, v.139, p.2075-2081, 1993.

FELSENSTEIN, J. Confidence limits on phylogenies: an approach using the bootstrap. Evolution, v.3, p.783-791, 1985.

FERREIRA, M.E.; GRATTAPAGLIA, D. Classes de marcadores moleculares para análise genética. In: FERREIRA, M.E.; GRATTAPAGLIA, D. Introdução ao uso de marcadores moleculares em análise genética. 2.ed. Brasília: Embrapa, Cenargen, 1996. p.13-68.

FERRON, P. Biological control of insect pests by entomogenous fungi. Annual Review of Entomology, v.23, p.409-442, 1978. 
FOSTER, L.M.; KOZAK, K.R.; LOFTUS, M.G.; STEVENS, J.J.; ROSS, I.K. The Polymerase Chain Reaction and its application to filamentous fungi. Mycological Research, v.97, n.7, p.769-781, 1993.

FOULY, H.; WILKINSON, H.T.; CHEN, W. Restriction analysis of internal transcribed spacers and the small subunit gene of ribossomal DNA among four Gaeumannomyces species. Mycologia, v.89, p.590-597, 1997.

FREIRE, L.L.C.; COSTA, A.B.L.; GÓES, L.B.; OLIVEIRA, N.T. de. DNA Polymorphism and Total Protein in Mutants of Metarhizium anisopliae var. anisopliae (Metsch.) Sorokin Strain Eg. Brazilian Journal of Microbiology, v.32, p.93-97, 2001.

FUNGARO, M.H.P.; VIEIRA, M.L.C.; PIZZIRANI-KLEINER, A.A.; AZEVEDO, J.L. Diversity among soil and insect of Metarhizium anisopliae var. anisopliae detected by RAPD. Letters in Applied Microbiology, v.22, n.6, p.389-392, 1996.

FUXA, J.R.; TANADA, Y. The pathogen population. In: TANADA, Y.; FUXA, J.R. (Ed.). Epizootiology of insects diseases. New York: John Willey and Sons, 1987. cap.5, p.112-140.

GARBER, R.C.; YODER, O.C. Isolation of DNA from filamentous fungi and separation into nuclear, mitocondrial, ribossomal, and plasmid components. Analytical Biochemistry, v.135, p.416-422, 1983.

GARGAS, A.; DEPRIEST, P.T. A nomenclature for fungal PCR primers with examples from intron-containing Ssu rDNA. Mycologia, v.88, n.5, p.745748, 1996.

HACKMAN, R.H. Chemistry of the insect cuticle. In: ROCKSTEIN, M. (Ed.). The physiology of insecta. New York: Academic Press, 1974. p.215-270. 
HEGEDUS, D.D.; KHACHATOURIANS, G.G. Construction of cloned DNA probes for the specific detection of the entomopathogenic fungus Beauveria bassiana in grasshopers. Journal of Invertebrate Pathology, v.62, p.233-240,1993a.

HEGEDUS, D.D.; KHACHATOURIANS, G.G. Identification of molecular variants in mitochondrial DNAs of members of the genera Beauveria, Verticillium, Paecilomyces, Tolypocladium, and Metarhizium. Applied Environmental Microbiology, v.59, p.4283-4288, 1993b.

HEGEDUS, D.D.; KHACHATOURIANS, G.G. Detection of the entomopathogenic fungus Beauveria bassiana within infected migratory grasshoppers (Melanoplus sanguinipes) using Polymerase Chain Reaction and DNA probe. Journal of Invertebrate Patholology, v.67, p.21-27, 1996b.

HEGEDUS, D.D.; KHACHATOURIANS, G.G. Identification and differentiation of the entomopathogenic fungus Beauveria bassiana using Polymerase Chain Reaction and Single-Strand Conformation Polymorphism Analysis. Journal of Invertebrate Patholology, v.67, p.289-299, 1996a.

HODGE, K.T.; SAWYER, A.J.; HUMBER, R.A. RAPD-PCR for identification of Zoophthora radicans isolates in biological control of potato leafhopper. Journal of Invertebarte Pathology, v.65, n.1, p.1-9, 1995.

HUGHES, K.W.; TOYOHARA, T.L.; PETERSEN, R.H. DNA sequence and RFLP analysis of Pleurotopsis longinqua from three disjunct populations. Mycologia, v.90, n.4, p.595-600, 1998. 
JENSEN, A.B.; EILENBERG, J. Genetic variation within the insect-pathogenic genus Entomophthora, focusing on the E. muscae complex, using PCRRFLP of the ITS II and LSU rDNA. Mycological Research, v.105, p.307312, 2001.

JIANG, L.; HIRUKI, C. Polymerase Chain Reaction amplification and restriction analysis of the ribosomal DNA of Olpidium radicale. Journal of Microbiological Methods, v.26, p.87-93, 1996.

KAIJIANG, L.; ROBERTS, D.W. The production of destruxins by the entomogenous fungus Metarhizium anisopliae var. major. Journal of Invertebrate Patholology, v.47, p.120-122, 1986.

KAVA-CORDEIRO, V. Cariótipos eletroforéticos de linhagens selvagens e mutantes do fungo entomopatogênico Metarhizium anisopliae (Metsch.) SOROKIN. Curitiba, 92p. Tese (M.S.) - Universidade Federal do Paraná.

KOSIR, J.M.; MacPHERSON, J.M.; KHACHATOURIANS, G.G. Genomic analysis of virulent strain of the entomopathogenic fungus Beauveria bassiana, using restriction fragment length polymorphisms. Canadian Journal of Microbiology, v.37, p.534-541, 1991.

KUCERA, M. Partial purification and properties of Galleria melonella larvae proteolytic inhibitors acting on Metarhizium anisopliae toxic protease. Journal of Invertebrate Pathology, v.43, p.190-196, 1984.

LEAL, S.C.M.; BERTIOLI, D.J.; BUTT, T.M.; PEBERDY, J.F. Characterization of isolates of the entomopathogenic fungus Metarhizium anisopliae by RAPD-PCR. Mycological Research, v.98, n.9, p.1077-1081, 1994. 
LEAL, S.C.M.; BERTIOLI, D.J.; BUTT, T.M.; CARDER, J.H.; BURROWS, P.R.; PEBERDY, J.F. Amplification and restriction endonuclease digestion of the Pr1 gene for the detection and characterization of Metarhizium strains. Mycological Research, v.101, n.3, p.257-265, 1997.

LEITE, B.; MESSIAS, C.L. Atividade enzimática para linhagens de Metarhizium anisopliae. Ciência e Cultura, v.36, p.814, 1984.

LEITE, B. Variabilidade de linhagens de Metarhizium anisopliae, quanto à atividade enzimática, resistência à luz ultra -violeta e virulência ao vetor da doença de Chagas Panstrongylus megistus. Campinas, 1987, 139p. Tese (M.S.) - Universidade Estadual de Campinas.

LUNA, E.A.; AZEVEDO, J.L. Obtenção de possíveis diplóides entre linhagens de Metarhizium anisopliae. Ciência e Cultura, v.37, p.721, 1985. /Apresentado à 12. Reunião Anual da SBPC, Belo Horizonte, 1985 Resumo/

LUNA, E.A. Características citológicas e genéticas de linhagens selvagens, mutantes e diplóides de Metarhizium anisopliae (Metsch) SOROKIN. Rio de Janeiro, 1985. 260p. Tese (Doutorado) - Universidade Federal do Rio de Janeiro.

MADELIN, M.F. Fungal parasits of insects. Annual Review of Entomology, v.11, p.423-448, 1966.

MANIATIS, T.; FRITSCH, E.F.; SAMBROOK, J. Molecular cloning: a laboratory manual. Cold Spring Harbor: Cold Spring Harbor Laboratory, 1982. 545p.

MARQUES, E.K.; IKUTA, N.; LUNGE, V.R.; FONSECA, A.S.K. Diagnóstico molecular e biotecnologia. In: SERAFINI, A.M.; BARROS, N.M.; AZEVEDO, 
J.L. (Ed.). Biotecnologia: avanços na agricultura e na agropecuária. Caxias do Sul: EDUCS, 2002. p.101-130.

MESSIAS, C.L. Parassexualidade em Metarhizium anisopliae (Metsch) SOROKIN. Piracicaba, 1979. 73p. Tese (Doutorado) - Escola Superior de Agricultura "Luiz de Queiroz", Universidade de São Paulo.

MESSIAS, C.L.; AZEVEDO, J.L. Parassexuality in the deuteromycete Metarhizium anisopliae. Transations of British Mycological Society, v.75, p.473-477, 1980.

MESSIAS, C.L. Fungos, sua utilização para controle de insetos praga de importância médica e agrícola. Memórias do Instituto Oswaldo Cruz, v.84, p.57-59, 1989.

MESSIAS, C.L.; PUPIN, A.M. The cuticular componentes from Diatraea saccharalis and their effect on "in vitro" growth of Metarhizium anisopliae var. anisopliae. In: INTERNATIONAL COLLOQUIUM ON INVERTEBRATE PATHOLOGY AND MICROBIAL CONTROL, 5., Adelaide, 1990. Proceedings. Adelaide: SIP, 1990. p.315.

MOZES-KOCH, R.; EDELBAUM, O.; LINERH, A. ; STEJNBERG, A.; UZIEL, A.; GERSON, U.; SELA, I. Identification of Hirsutella species isolates within a species and intraespecific heterokaryons by Random Amplified Polymorphic DNA (RAPD). Journal of Plant Disease Protection, v.102, p.284-290, 1995.

NEUVEGLISE, C.; BRYGOO; Y.; VERCAMBRE; B.; RIBA; G. Comparative analysis of molecular and biological characteristics of strains of Beauveria brongniartii isolated from insects. Mycological Research, v.98, p.322-328, 1994. 
ONOFRE, S.B.; VARGAS, L.R.B.; ROSSATO; M.; BARROS, N.M.; BOLDO, J.T.; NUNES, A.R.F.; AZEVEDO, J.L. Controle biológico de pragas na agropecuária, por meio de fungos entomopatogênicos. In: SERAFINI, L.A.; BARROS, N.M.; AZEVEDO, J.L. (Org.). Biotecnologia: avanços na agricultura e na agroindústria. Caxias do Sul: EDUCS, 2002. p.295-328.

OUELLET, T.; SEIFERT, K.A. Genetic characterization of Fusarium graminearum strains using RAPD and PCR amplification. Phytopathology, v.83, n.9, p.1003-1007, 1993.

PAAVANEN-HUHTALA, S.; AKINAINEN, H.; YLFMATTILA, T. Development of strain-specific primers for a strain of Gliocladium catenulatum used in biological control. European Journal of Plant Pathology, v.106, p.187198, 2000.

PARIS, S.; FERRON, P. Study of the virulence some mutants of Beauveria brongniartii (= Beauveria tenella). Journal of Invertebrate Pathology, v.7, p.71-77, 1979.

PECCHIA, S.; MERCATELLI, E.; VANNACCI, G. PCR amplification and characterization of the intergenic spacer region of the ribosomal DNA in Pyrenophora graminea. FEMS Microbiology Letters, v.166, p.21-27, 1998.

PEKRUL, S.; GRULA, A. Mode of the corn earworm Heliothis zea by Beauveria bassiana as revealed by scanning Electron Microscopy. Journal of Invertebrate Pathology, v.34, p.238-247, 1979.

PFEIFER, T.A.; KHACHATOURIANS, G.G. Isolation of DNA from entomopathogenic fungi grown in liquid cultures. Journal of Invertebrate Pathology, v.61, p.113-116, 1993. 
PONTECORVO, G.; ROPER, J.A.; HEMONS, J.M; Mac DONALD, K.D.; BUTTON, A.W.J. The genetics of Aspergillus nidulans. Advances in Genetics, v.5, p.141-238, 1953.

RAKOTONIRAINY, M.S.; CARIOU, M.L.; BRYGOO, Y.; RIBA, G. Phylogenetic relationships within the genus Metarhizium based on 28S rRNA sequences and isozyme comparison. Mycological Research, v.98, p.225-230, 1994.

RISTAINO, J.B.; MADRITCH, M.; TROUT, C.L.; PARRA, G. PCR amplification of ribossomal DNA for species identification in the plant pathogen genus Phytophtora. Applied Environmental Microbiology, v.63, n.3, p.948-954, 1998.

ROBERTS, D.W. Toxins from the entomogenous fungus Metarhizium anisopliae. I. Production in submerged and surface cultures, and an inorganic and organic nitrogen media. Journal of Invertebrate Pathology, v.8, p.212-221, 1966a.

ROBERTS, D.W. Toxins from the entomopatogenous fungus Metarhizium anisopliae. II. Symptoms and detection in moribund hosts. Journal of Invertebrate Pathology, v.8, p.222-227, 1966b.

ROBERTS, D.W. Toxins from the entomogenous fungus Metarhizium anisopliae: isolation of destruxins from submerged cultures. Journal of Invertebrate Pathology, v.14, p.82-88, 1969.

ROBERTS, D.W.; YENDOL, W.G. Use of fungi for microbial control of insects. In: BURGES, H.D. (Ed.). Microbial control of insects and mites. New York: Academic Press, 1971. p.125-149.

ROBERTS, D.W. World picture of biological control of insects by fungi. Memórias do Instituto Oswaldo Cruz, v.84, n.3, p.89-100, 1989. 
ROHLF, F.J. NTSYS-pc numerical taxonomy and multivariate analysis system (software). Version 150. New York: Exeter Publisher, 1992.

SAITOU, N.; NEI, M. The neighbor-joining method: a new method for reconstructing phylogenetic trees. Molecular Evolution of Biology, v.4, p.406-425, 1987.

SCHABEL, H.G. Percutaneous infection of Hylobius pale by Metarhizium anisopliae. Journal of Invertebrate Pathology, v.31, p.180-187, 1978.

SCHRANK, A.; VAINSTEIN, M.H. Metodologia da tecnologia do DNA recombinante: uma visão geral de seus princípios. In: SERAFINI, L.A; BARROS, N.M; AZEVEDO, J.L. (Org.). Biotecnologia: avanços na agricultura e na agroindústria. Caxias do Sul: EDUCS, 2002. p.13-44.

SILVA, J.C.; MESSIAS, C.L. Virulence of mutants and revertents of Metarhizium anisopliae var. anisopliae toward Rhodnius prolixus. Journal of Invertebrate Pathology, v.48, p.368-374, 1986.

SILVA, J.C. Virulência de mutantes exoenzimáticos de Metarhizium anisopliae e seus revertentes a Rhodnius prolixus. Campinas, 1985. 161p. Tese (Doutorado) - Universidade Estadual de Campinas.

SILVEIRA, W.D. Obtenção e fusão de protoplastos em Metarhizium anisopliae (Metsch.) SOROKIN. Piracicaba, 1983. 153p. Dissertação (M.S.) - Escola Superior de Agricultura "Luiz de Queiroz", Universidade de São Paulo.

SOSA-GÓMEZ, D.R.; TIGANO, M.S.; ARANTES, O.M.N. Caracterização de entomopatógenos. In: ALVES, S.B. (Ed.). Controle microbiano de insetos. 2.ed. Piracicaba: FEALQ, 1998. p.731-764. 
St. LEGER, R.J.; CHARNLEY, A.K.; COOPER, R.M. Cuticle-degrading enzimes of entomopathogenic fungi: mechanisms of interaction between pathogen enzymes and insect cuticle. Journal of Invertebrate Pathology, v.47, p.295-302, 1986a.

St. LEGER, R.J.; ROBERTS, D.W.; STAPLES, R.C. Calcium and calmodulinmediated protein synthesis and protein phosphorylation during germination, growth and protease production by $M$. anisopliae. Journal of General Microbiology, v.135, p.2141-2154, 1989.

St. LEGER, R.J.; GOETTEL, M.; ROBERTS, D.W.; STAPLES, R.C. Prepenetration events during infection of host cuticle by $M$. anisopliae. Journal of Invertebrate Pathology, v.58, p.168-179, 1991.

St. LEGER, R.J.; STAPLES, R.C.; ROBERTS, D.W. Entomopathogenic isolates of Metarhizium anisopliae, Beauveria bassiana and Aspergillus flavus produce multiple extracellular chitinase isozymes. Journal of Invertebrate Pathology, v.61, p.81-84, 1993.

STRONGMAN, D.B.; MACKAY, R.M. Discrimination between Hirsutella longicolla var. longicolla and Hirsutella longicolla var. cornuta using Random Amplified Polymorphic DNA fingerprinting. Mycologia, v.85, n.1, p.65-70, 1993c.

THOMSEN, L; JENSEN, A.B. Application of nested-PCR technique to resting spores from the Entomophthora muscae species complex: implications for analyses of host-pathogen population interactions. Mycologia, v.94, n.5, p.794-802, 2002.

TIGANO-MILANI, M.S.; GOMES, A.C.M.M.; SOBRAL, B.W.S. Genetic variability among brazilian isolates of the entomopathogenic fungus M.anisopliae. Journal of Invertebrate Pathology, v.65, p.206-210, 1995. 
TINLINE, R.D.; NOVIELLO, C. Heterokaryosis in the entomogenous fungus Metarhizium anisopliae. Mycologia, v.63, p.701-712, 1971.

UETAKE, Y.; ARAKAWA, M.; NAKAMURA, H.; AKAHIRA, T.; SAYAMA, A.; CHEAH, L.H.; OKABE, I.O.; MATSUMOTO, N. Genetic relationship among violet root rot fungi as revealed by hyphal anastomosis and sequencing of the rDNA ITS regions. Mycological Research, v.106, p.156-163, 2002.

VEEN, K.H. Recherches sur la maladie, due à Metarhizium anisopliae chez le criquet pèlerin. Mendelingen Landbouwhogeschool, v.68, p.1-77, 1968.

WELSH, J.; MCCLELLAND, M. Fingerprinting genomes using PCR with arbitrary primers. Nucleic Acids Research, v.18, n.24, p.7213-7218, 1990.

WHITE, T.J.; BRUNS, T.D.; LEE, S.B.; TAYLOR, J.W. Analysis of phylogenetic relationships by amplification and direct sequencing of ribosomal DNA genes. In: INNIS, D.H.; SNINSKY, J.J.; WHITE, T.J. PCR PROTOCOLS: a guide to methods and applications. New York: Academic Press, 1990. p.315-322.

ZACHARUCK, R.Y. Fine structure of the fungus Metarhizium anisopliae infecting three species of larvae elateridae (Coleoptera). I. Dormant and germinating conidia. Journal of Invertebrate Pathology, v.15, p.63-80, 1970a.

ZACHARUCK, R.Y. Fine structure of the fungus Metarhizium anisopliae infecting three species of larvae elateridae (Coleoptera). II. Conidial germ tubes and apressoria. Journal of Invertebrate Pathology, v.15, p.81-91, 1970b. 
ZACHARUCK, R.Y. Fine structure of the fungus Metarhizium anisopliae infecting three species of larvae elateridae (Coleoptera). III. Penetration of the host integument. Journal of Invertebrate Pathology, v.15, p.372-396, 1970c.

ZACHARUCK, R.Y. Penetration of the cuticular layers of elateridae larvae (Coleoptera) by the fungus Metarhizium anisopliae and notes on a bacterial invasion. Journal of Invertebrate Pathology, v.21, p.101-106, 1973. 